Din ve Bilim - Muş Alparslan Üniversitesi İslami İlimler Fakültesi Dergisi Region and Science - Journal of Muş Alparslan University Faculty of Islamic Sciences e-ISSN: 2667-7717 Haziran/June 2021, 4(1): 108-127

\title{
Ebû Hanîfe'nin Hukuk Düşüncesinde Farazî Fıkıh
}

Hypothetical Fiqh in Abu Hanifa's Thought of Law

\author{
Halil KILIÇ \\ Arş. Gör. Dr., Muş Alparslan Üniversitesi, İslami İlimler Fakültesi, İslam Hukuku \\ Anabilim Dalı \\ Research Assistant Doctor, Muş Alparslan University, Faculty of Islamic Sciences, \\ Department of İslamic Law, Muş/Turkey \\ h.kilic@alparslan.edu.tr \\ ORCID: 0000-0002-7424-7212

\section{Makale Bilgisi | Article Information} \\ Makale Türü / Article Type: Araştırma Makalesi / Research Article \\ Geliş Tarihi / Date Received: 20 Mayıs / May 2021 \\ Kabul Tarihi / Date Accepted: 21 Haziran / June 2021 \\ Yayın Tarihi / Date Published: 30 Haziran / June 2021 \\ Yayın Sezonu / Pub Date Season: Haziran / June \\ DOI: $10.47145 /$ dinbil.940173
}

Bu makale, "İslam Hukuk Düşüncesinde Farazî F1kıh" (Atatürk Üniversitesi, Sosyal Bilimler Enstitüsü, 2021) başlıklı doktora tezinden üretilmiştir./ This Article is Extracted from my doctoral dissertation entitled "Hypothetical Fiqh in Islamic Law Thought", supervised by Prof. Dr. Ali İhsan PALA (Atatürk University, Institute of Social Sciences, Erzurum/Turkey, 2021).

Atıf / Citation: Kılıç, Halil. "Ebû Hanîfe'nin Hukuk Düşüncesinde Farazî Fıkıh / Hypothetical Fiqh in Abu Hanifa's Thought of Law". Din ve Bilim - Muş Alparslan Üniversitesi İslami İlimler Fakültesi Dergisi 4 / 1 (Haziran 2021): 108-127. doi:

$$
\text { 10.47145/dinbil.940173 }
$$

İntihal: Bu makale, iThenticate yazılımınca taranmıştır. İntihal tespit edilmemiştir.

Plagiarism: This article has been scanned by iThenticate. No plagiarism detected. web: https://dergipark.org.tr/tr/pub/dinbil I mailto: dinbil@alparslan.edu.tr

Copyright @ Published by Muş Alparslan Üniversitesi, İslami İlimler Fakültesi / Muş Alparslan University, Faculty of Islamic Sciences, Muş, 49250 Turkey.

Bütün hakları saklıdır. / All right reserved. 


\title{
Öz
}

Kaynakları vahye dayanan İslâm hukuku sahâbe ve tâbiûn dönemini kapsayan hicrî birinci asırda vakıa eksenli bir seyir izlemiştir. Bu evrede fıkıh konuları ele alınırken detaylandırılmıyor, fakîhler vuku bulmuş ve aktüalitesi bulunan meseleler hakkında bireysel içtihatlar yapıyorlardı. Ancak ikinci asırda bu durum farklı bir yönde gelişme göstermeye başlamıştır. Bölgesel yapılanmaları ifade eden Iraklılar ve Hicâzlılar ayrışması, yerini, şerî hükümlere ulaşmada takip edilen yöntem farklılığını ifade eden ehl-i re'y ve ehl-i hadîs ekollerine peyderpey birakmıştır. Kûfe merkezli ehl-i re'yin en önemli siması olan Ebû Hanîfe, İslâm hukukunu, birbirinden bağımsız meselelerden ve bu meselelere ait içtihatlardan oluşan dağınık yapısından kurtaracak bir faaliyete imza atmıştır. Günümüzde "farazî fıkıh" olarak adlandırılan ve vuku bulmamış varsayımsal meseleler hakkında içtihadı ifade eden bu faaliyet, İslam hukukunun doktriner hukuk sistemine dönüşümünü sağlayan etkenlerden biri olmuştur. Farazî fıkhın ilk nüvelerine vahiy dönemi ve sonrasında rastlanıyorsa da Ebû Hanîfe, bu yöntemi bütün fıkıh konularına uygulayarak sistemleştirmiştir. Ebû Hanîfe tarafından bu yöntemle oluşturulmuş meseleler, diğer mezheplerin gelişiminde de etkili olmuştur. Ebû Hanîfe'nin fıkıh faaliyetlerinde farazî meseleler birçok amaçla kullanılmıştır. Kendisinin ifadesiyle farazî fıkıh, geleceğe yönelik bir hukuk inşası olduğundan, adaletin temini noktasında hukukçuya yardımcı olmaktadır. Fıkıh konuları arasında aklî ve mantıkî örüntüyü sağlayarak bütüncül bir bakış açısı sunmaktadır. Fıkıh eğitiminde öğrencinin varsayımsal meseleler üzerinde yeteneğini test etmesine ve eksik yönlerini görmesine olanak sağlamaktadır. Bu yönüyle farazî fıkıh, İslâm hukukunun pratikte uygulanmasına yarar sağladığı gibi Ebû Hanîfe'nin hukuk düşüncesinin bir mezhep olarak teorik gelişiminin sacayaklarından biri olmuştur.

Anahtar kelimeler: İslam Hukuku, Ebû Hanîfe, Ehl-i Re’y, Farazî Fıkıh, İçtihat.

\begin{abstract}
Islamic law, whose sources are based on revelation, in the first century AH, followed a fact-oriented course covering the period of sahabah and tabiun. At this stage, dealing with fiqh issues, they were not detailed, but jurists took place and made individual ijtihads on issues of actuality. However, this situation reversed in the second century. The conflict of the Iraqis and the Hijazis, in the expressing regional structuring, has been replaced by the ahl al ra'y and ahl al hadith schools, which express the difference in the method followed in achieving religious provisions. Abu Hanifa, who is the most important figure of the Ahl al ra'y that centered on Kufa, carried out an activity that would save the Islamic law from the independent issues and the dispersed structure of ijtihads belonging to these issues. Today, this activity, which is called "hypothetical fiqh" and expresses ijtihad about hypothetical issues that have not occurred, has been one of the actors that have transformed Islamic law into a doctrinal legal system. Although the first examples of hypothetical fiqh are found during and after the revelation period, Abu Hanifa has systematized this method by applying it to all fiqh issues. The issues created by Abu Hanifa with this method also influenced the development of other madhhabs. In Abu Hanifa's fiqh activities, hypothetical issues were used for many purposes. As he stated, hypothetical fiqh helps the jurist at the point of ensuring justice, since it is a future-oriented law construction. It provides a holistic perspective by providing the rational and logical pattern among fiqh topics. And allows the student to test his ability on hypothetical issues and to see his deficiencies in fiqh education. In this respect, the hypothetical fiqh has been beneficial to the practice of Islamic law and has become one of the pillars of the theoretical development of Abu Hanifa's legal thought as a sect.
\end{abstract}

Keywords: Islamic law, Abu Hanifah, Ahl-i Re'y, Hypothetical Fiqh, Ijtihad 


\section{Giriş}

İslâm hukuku, kaynağı itibarıyla ilâhî bir hukuk sistemidir. İlahî vahyin tedricen ve peyderpey nazil olduğu risâlet döneminde amelî hükümlere yönelik teşrî, yaşanılan vakıalara yöneliktir. Bu bakımdan vahiy döneminde detaylı meseleler hakkında hüküm teşrîi söz konusu değildir. Vakıalar gerçekleştikçe Hz. Peygamber'e sorular soruluyor ve $\mathrm{O}$ da bu vakıaların hükmünü beyan ediyordu. Nitekim Kur'ân ve Sünnet'te yer alan hükümler aşırı detaylı, derli toplu ve sistematik değildir. Bu iki kaynakta kısmen detaylı hükümler yer alsa da bunlar, günlük hayatta karşılaşılabilir olağan meselelerdir.

Hz. Peygamber'in (s.a.v) vefatından sonra vahye dayalı teşrî söz konusu olmayacağ1 için Müslümanların karşılaştığı olayların şerî hükmünü ortaya koyma işi, daha teknik bir ifadeyle içtihat, bu işe ehil olanlar açısından bir zorunluluk olmuştur. Fetih hareketleri nedeniyle İslâm coğrafyası giderek genişlediği için karşılaşılan ve çözüm bekleyen hadiseler, hem farklılaşmış hem de girift bir yapıya bürünmüştür. Bu bakımdan nasslardan hüküm çıkarmada re'yi kullanma gerekliliği daha da artmıştır. Ancak bu dönemde re'y ile içtihada zaruret mesabesinde başvurulmuş, henüz gerçekleşmemiş meseleler varsayılarak bir fıkıh konusuyla alakalı detaylı ve sistematik analizler yapılmamıştır. Farazî meseleler üretmeye dayalı doktriner bir içtihat faaliyeti bulunmadığından sahâbe dönemi hukuk anlayışı da aktüel meseleler üzere kurulu güncel bir görünüm arz etmiştir.

Tâbiûn döneminin hicrî birinci asrın sonlarına kadarki bölümünde de fıkhî faaliyetlerde vakıîlik söz konusudur. Ancak hicrî birinci asrın sonlarıyla birlikte İslam hukukunun seyri açısından önemli gelişmeler yaşanmıştır. Zira bu dönemde Sünnet'in tedvini başlamış, ilmî seyahatler çoğalmış ve bunlara bağlı olarak da Emeviler döneminde daha çok genişleyen İslam topraklarının farklı bölgelerinde yaşayan tebaaya ait meseleler farklı merkezlerdeki ilim halkalarında tartışılır olmuştur. Sahabe döneminden itibaren "Iraklılar" ve "Hicâzlılar" şeklinde bölgesel oluşumları gösteren ifadelerin yerini, nasslardan ve rivayetlerden hüküm çıkarmadaki metot farklılığını ifade eden "ehl-i re'y" ve "ehl-i hadîs/eser" gibi ekoller almıştır. Bütün bu gelişmeler İslâm hukukunun teorik gelişiminin kat ettiği mesafeyi göstermektedir. İşte bu dönemde Kûfe ehl-i re'y ekolünün temsilcisi olan Ebû Hanîfe (ö. 150/767), önceki dönemlerde kısmen varlığı bulunan bir ameliyeyi aktif bir şekilde kullanarak geliştirmiştir. Onun sistemleştirerek geliştirdiği bu ameliye, günümüz literatürüne "farazî/takdîrî fıkıh" olarak geçmiştir.

Ebû Hanîfe, yaklaşık bir asırlık birikimden müteşekkil fıkıh meselelerini kendi içtihat usûlü üzerinden yeniden yapılandırmıştır. $\mathrm{O}$, kuramsal ve doktriner bir hukuk düşüncesi inşa etmek için yalnızca mevcut birikimle yetinmeyip, henüz gerçekleşmemiş meseleleri varsayarak mevcut birikimle harmanlamıştır. Onun, adeta bir hukuk/fıkıh akademisi niteliğindeki ilim halkasındaki ashâbıyla birlikte oluşturduğu ve birçoğu Şeybânî’nin (ö. 189/805) eserleriyle günümüze intikal etmiş meseleler, yalnızca Hanefîliğin değil, diğer mezheplerin gelişim seyrine de yön vermiştir. Zira Mâlikî fıkhının farazî fıkıh eksenli ilk telifleri olan el-Esediyye ve el-Müdevvene'nin ihtiva etmiş oldukları meseleler, Şeybânî'nin eserlerinden devşirilmiştir. Aynı şekilde İmam Şâfiî́nin (ö. 204/820) de Şeybânî'nin öğrenciliğini yapmakla bu meselelerden istifade ettiği bilinmektedir. ${ }^{1}$ Kolektif bir çalışmanın ürünü olan bu meseleler, İslâm hukukunun bir bilim olarak gelişiminde baş aktörlerden biri olmuştur. Nitekim Ebû Hanîfe'den sonra gelen fukahâ, mezkûr meseleler üzerinden kendi düşünce sistemlerini daha da ileriye taşımışlardır. Fukahânın hukukî mekanizmada boşluk bırakmamaya yönelik sivil

${ }^{1}$ Bkz.: Halil Kılıç, “İmâm Şâfiı̂’de Farazî Fıkıh”, İslam Düşüncesi Araştırmaları II. ed. Mahsum Aytepe-Hasan Kaya (Ankara: Araştırma yay., 2020), 38. 
çabaları ve bu çabaların ürünü olarak ortaya çıkmış meseleleri ihtiva eden literatür, asırlar boyunca İslâm toplumunda resmî bir kanunlaştırmaya ihtiyaç bırakmamıştır. Farazî fıkıh ameliyesi sayesinde İslam hukukçuları, hayatın bütün alanına nüfuz etmişler ve çözüme kavuşturulmamış vuku bulmuş bir hadise ya da gerçekleşmesi muhtemel mesele bırakmamayı amaçlamışlardır. Ayrıca farazî fıkıh, sınırlı sayıdaki nass ve rivayetlere rağmen İslâm hukukuna dinamizm kazandırmış ve İslâm hukukunun her zaman ve zeminde uygulanabilirliğini sağlamıştır.

İşte bu çalışmada İslâm hukukunun tatbıkî-amelî bölümünün (füru-u fıkıh) gelişiminin yapı taşlarından birini oluşturan "farazî fıkıh"1n, onu sistemleştiren İmâm-1 A'zam Ebû Hanîfe'nin hukuk düşüncesindeki rolü ele alınacaktır.

\section{Farazî Fıkhın Mahiyeti ve İşlevi}

"Farazî fıkıh" ifadesi "farazî" ve "fıkıh" kelimelerinden müteşekkil bir sıfat tamlamasıdır. Bu tamlamanın ilk kelimesi olan "farazî" kelimesi Arapça "ض ض / fard" köküne nispet edilmiş ism-i mensûb bir ifadedir. Bu kök, sözlükte "bir şeyi zorunlu kılmak, açıklamak, takdir etmek, belirlemek, kesinleştirmek, sınır belirlemek, ölçmek" gibi anlamlarda kullanılmaktadır.² Ancak bu kök, "farazî fıkıh" tamlamasında sözlük anlamları içerisinde yer almayan ve hicrî ikinci asır ve sonrasında kaleme alınmış Arapça felsefe ve mantık metinlerinde kazandığı "varsayım/varsaymak" anlamında kullanılmıştır. ${ }^{3}$ Tamlamanın bir diğer kelimesi olan "fıkıh" ise sözlükte "bir şeyi derinlemesine bilmek ve kavramak" anlamına gelmektedir. ${ }^{4}$ Bir terim olarak fıkıh, "tafsîlî delillerden elde edilen şerî-amelî hükümleri bilmek" şeklinde tanımlanmaktadır. ${ }^{5}$ Tamlamayı bir bütün halinde "varsayımsal fıkıh" şeklinde tercüme edebiliriz.

İslam hukuk düşüncesinin doktriner bir yapıya bürünmesi ve literal gelişiminde, varsayımsal meseleler üzerinde hukuk yapma faaliyetleri önemli bir rol üstlenmişse de bu faaliyeti ifade eden bir isimlendirmeye veya tanıma klasik kaynaklarda rastlanmamaktadır. XX. yüzyıldan sonra İslam hukuku alanında kaleme alınmış çalışmalarda bu faaliyeti ifade eden birçok isimlendirme ve tanımlama girişimi mevcuttur. ${ }^{6}$ Yapılan tanımlar, farazî fıkhın, henüz gerçekleşmemiş varsayıma dayalı meselelerin fıkıh faaliyetlerinde kullanılması paydasında birleşmektedir. Buna göre farazî fıkhı, "Henüz vuku bulmamış varsayımsal meselelerin tafsîlî delillerden elde edilen şerî amelî hükümlerini bilmek"7 şeklinde tanımlamak mümkündür.

İslâm hukuk düşüncesinin gelişiminde farazî fıkhın birçok işlevi bulunmaktadır. Farazî fıkhın belki de en önemli işlevi, bir fıkıh başlığına (kitâb-bâb) ait kuramsal çerçeveyi inşa etmeye yardımcı olmasıdır. Bu bakımdan fürû-u fıkhın klasik tasnifini teşkil eden ibâdât (ibadetler hukuku), muâmelât (alışveriş hukuku), münâkehât (aile hukuku) ve ukubât (ceza hukuku) konuları ve bunları oluşturan

\footnotetext{
${ }^{2}$ Halîl b. Ahmed el-Ferâhîdî, Kitabu'l-'Ayn. thk. Abdülhamîd el-Hendâvî, (Beyrut: Daru'l-Kutubi'l-İlmiyye, 2003), 3: 313; İsmâîl b. Hammâd el-Cevherî, es-Sihâh Tâcu'l-Lüğa ve Sihâhu'l-'Arabiyye. thk. Ahmed Abdülğafûr Attâr, 4. Baskı, (Beyrut: Dâru'l-İlm li'l-Melâyîn, 1990), 3: 1097; Ebu'l-Fadl Cemâluddîn Muhammed b. Mukerrem b. Manzûr, Lisânu'l-'Arab, (Beyrut: Dâru Sadır, h. 1414), 7: 202-206.

${ }^{3}$ Kılıç, "İmâm Şâfiî̀'de Farazî Fıkıh", 28.

${ }^{4}$ Cevherî, es-Sihâh, 1990: 6: 2243; İbn Manzûr, Lisânu'l-'Arab, 5: 3450.

5 Seyyid Şerîf Ali b. Muhammed b. Ali el-Cürcânî, Mu'cemü't-Ta'rîfât, thk. Muhammed Sıddık el-Minşâvî, (Kahire: Dâru'lFadîla, 1357/1938), 155.

6 İlgili bazı tanımlar ve isimlendirmeler için bkz.: Halil Kılıç, İslam Hukuk Düşüncesinde Farazî Fıkıh. (Erzurum: Atatürk Üniversitesi, Sosyal Bilimler Enstitüsü, Doktora Tezi, 2021), 26-30, 58.

7 Muhammed b. Abdillah b. Muhammed el-Muhaymîdî, "el-Fetvâ el-İftirâdiyye Mefhûmuhâ ve Ehemmiyyetuhâ ve Hukmuhâ", Mu'temeru'l-Fetvâ ve İstişrâfu'l-Mustakbel. (Suud: Câmi'atu'l-Kasîm, 1434), 1: 102.
} 
alt başlıklar, aşırı detaylı meselelerle işlenmiştir. Akla gelebilecek en ince ayrıntılar üzerinden meseleler varsayılarak bu konuların temel çerçeveleri ve kuramları belirlenmiştir. ${ }^{8}$ Buna göre farazî fıkıh, kuramsal fıkıh konularının oluşumunun yapı taşlarından biri olmuştur. Nitekim dağınık halde bulunan bilgilerle ve mevcut vakıalarla yetinmek, bir ilim dalının teşekkülü için kâfi değildir. Gerçekleşmiş hadiselere yönelik mevcut birikim, varsayımlarla desteklenmeli ve pekiştirilmelidir. ${ }^{9}$ İbn Cinnî (ö. 392/1002), bir ilim dalının oluşumu için o ilme özel mesele üretme fonksiyonunu gerekli görür ve bundan mahrum olan ilimlerin, sanatla yontulmamış oduna benzediğini söyler.10 $\mathrm{O}$, bu fonksiyona sahip ilimlerden birinin fıkıh olduğunu ifade eder. İşte fıkıh ilmi için bu önemli görevi, farazî fıkhın üstlendiği söylenebilir.

Farazî fıkhın işlevlerinden biri de geleceğe yönelik hukuk inşasını sağlamasıdır. Farazî fıkıh yöntemiyle oluşturulmuş gerçekleşmesi muhtemel meselelere yönelik içtihatlar, toplumun hukuk ihtiyacını karşılar. Farazî meseleler, herhangi bir zaman diliminde gerçekleştiği anda hükümler hazır bulunacağından hakkın ihkakı ve adaletin temini ivedilikle sağlanacaktır. Farazî fıkhın bu işlevinden hareketle meşru içtihadı farz-ı ayn, farz-1 kifâye ve mendûb şeklinde üçlü bir tasnife tabi tutan fakihler, gerçekleşmemiş hadiseler hakkında yapılan içtihadı mendûb kategorisinde değerlendirmişlerdir. ${ }^{11} \mathrm{Bu}$ meyanda, İslâm hukukçuları tarafından oluşturularak hükmü ortaya konmuş farazî fıkıh mahsulü meseleler, asırlar boyunca İslâm toplumunun hukuk ihtiyacını karşılamıştır. Bu meseleleri ihtiva eden eserler, adlî vakaların çözüme kavuşturulmasında bir kaynak olarak telakki edilmiş ve İslâm devletlerinde yeni bir kanunlaştırmaya ihtiyaç bırakmamıştır. Önceki asırlarla kıyaslanmayacak derecede meselelerin girift bir yapıya büründügü günümüzde dahi, İslam hukukçuları, bu içtihatlardan yararlanmaktadırlar. ${ }^{12}$

Farazî fıkıh, hukukun işleyişine sağladığı katkıların yanı sıra fıkıh talebelerinin yeteneklerini test etmek, ulaştıkları seviyeyi tespit, zihin jimnastiği yaptırmak, eksik yönlerini görmesini sağlamak ve becerilerini geliştirmek gibi amaçlarla fıkıh eğitim ve öğretiminde bir yöntem olarak da kullanılmıştır. Gündelik hayatta karşılaşılmayacak ya da gerçekleşmesi imkânsız meseleler hakkında, fakîhin içtihatta bulunma ve cevap verme yükümlülüğü tartışmalı bir husus olsa da bu meselelerin, fıkıh eğitiminde kullanılabileceği ifade edilmektedir. ${ }^{13}$ Ayrıca fakîhler arasında gerçekleşen tartışmalarda da farazî meseleler bir ispat metodu olarak kullanılmıştır. Tartışmaların tarafları, görüşlerini rahatlıkla sunmak, desteklemek ve muhatabın anlamasını sağlamak gayesiyle farazî meselelerden yararlanmışlardır. ${ }^{14}$ Bunlar haricinde farazî fıkıh; doktriner düşünceyi geliştirmek, içtihat yapılırken göz önünde bulundurulan amaçları ve temel ilkeleri ortaya koymak, ${ }^{15}$ bütün fıkıh

\footnotetext{
${ }^{8}$ Mürtaza Bedir, Ebu Hanife-Entelektüel Biyografì. (Ankara: Ay Yayınları, 2018), 84-85

${ }^{9}$ Ernest Hirş, Hukuk Felsefesi ve Hukuk Sosyolojisi Dersleri. (Ankara: Banka ve Ticaret Hukuku Araştırma Enstitüsü Türkiye İş Bankası Vakfı Sözkesen Matbaacılık, 2001), 13.

${ }^{10}$ Ebü'l-Feth Osmân b. Cinnî el-Mevsılî, el-Hasâis. thk. Muhammed Ali Neccâr, (b.y.: Dâru'1-Kütübi'1-Misriyye, ts., 2: 92-93.

${ }^{11}$ Ebû Abdillah Ahmed b. Hamdân, el-Harrânî el-Hanbelî, Sıfetu'l-Fetvâ ve'l-Müftî ve'l-Müsteftî. thk. Nasıruddîn Albânî, (Beyrut: el-Mektebu'l-İslâmî, 1380), 30; Alâüddîn Abdülazîz b. Ahmed b. Muhammed el-Buhârî, Keşfü'l-Esrâr 'an Usûli Fahri'l-İslâm elPezdevî. thk. Abdullah Mahmûd Muhammed Ömer, (Beyrut: Dâru'l-Kütübi'l-İlmiyye, 1997), 4: 20-21.

${ }^{12}$ Kılıç, İmâm Şâfiî’ de Farazî Fıkı'”", 30.

${ }^{13}$ Şemsüleimme Ebû Bekr Muhammed b. Ebî Sehl Ahmed es-Serahsî, el-Mebsût. thk. Halil Muhyiddîn el-Meys, (Beyrut: Dâru'lFikr, 2000), 3: 161; Ebû Muhammed Ali b. Ahmed b. Said b. Hazm el-Endülûsî el-Kurtûbî ez-Zâhirî, et-Takrîb li Haddi'l-Mantık. (Beyrut: Daru İbn Hazm, 2007), 461-462; Hâfızuddîn b. Muhammed el-Bezzâzî, el-Kerderî el-Fetâva'l-Bezzâziyye. (Beyrut: elMatba'atü'l-Kübra'l-Emîriyye, 1310), 77; İbn Âbidîn Muhammed Emîn b. Ömer b. Abdilazîz el-Huseynî ed-Dimaşkî, Reddu'lMuhtâr 'ale'd-Durri'l-Muhtâr Şerhu Tenvîri'l-Ebsâr. (Riyâd: Dâru Âlemi'l-Kutub, 2003), 3: 46-47.

${ }^{14}$ Emîr Padişah Muhammed Emin, Teysîru't-Tahrîr. (Mısır: Matba'atü Mustafa el-Bâbî, 1351), 2: 148

${ }^{15}$ Saffet Köse, İslam Hukukuna Giriş. (İstanbul: Hikmetevi Yayınları, 2015), 158; Ali Bardakoğlu, "Hanefî Mezhebi", Türkiye Diyanet Vakfı İslâm Ansiklopedisi, (Ankara: TDV Yayınları, 1997), 16: 19-20.
} 
konularına çözümler getirerek hukuktaki boşlukları kapatmak, içtihat yöntemlerini test etmek, ${ }^{16}$ şekilsel açıdan birbirine benzerlik gösteren çözümlemeler arasında mantıksal tutarlık inşa etmek, ${ }^{17}$ nassları ve rivayetleri yorumlamak ve kapsam alanlarını belirlemek ${ }^{18}$ gibi hususlarda katkılar sunmaktadir.

\section{Ebû Hanîfe Öncesi Kûfe Hukuk Ekolünde Farazî Fıkıh Temayülü}

Vahiy döneminde şerî hükümler, güncel meselelere ve vakıalara odaklanmıştır. Ancak bu dönemde farazî meseleler hakkında asla hükmün vazedilmediği şeklinde bir genellemede bulunmak imkânsızdır. Gerek Kur'ân-1 Kerim'de gerek hadislerde henüz gerçekleşmemiş hadiselere yönelik hükümlerin vazedildiğini gösteren somut veriler bulunmaktadır. Hanbelî fakîh Necmeddîn et-Tûfî (ö. 716/1316), "Onlarla birlikte bulunup onlara namaz kıldırdığında onlardan bir bölük seninle beraber namaza dursun, silâhların da yanlarına alsınlar. Bunlar secde ettiklerinde ötekiler arkanızda olsunlar, sonra henüz namazların kılmamış bulunan bölük gelip seninle beraber namazların kılsınlar ve bunlar da ihtiyat tedbirlerini ve silâhlarını alsınlar... Eğer yağmur yüzünden bir zarar görürseniz veya hasta olursanız silâhlarınızı bırakmanızda size bir günah yoktur..."19 mealindeki ayette Allah Teâlâ'nın, vuku bulma ihtimalinden hareketle vukuundan önce yağmur ve hastalığın hükmünü açılladığını ifade eder. ${ }^{20} \mathrm{~Hz}$. Peygamber'in de farklı amaçlarla farazî meselelerden yararlandığını ya da kendisine sorulan henüz gerçekleşmemiş meselelere cevap verdiğini gösteren rivayetler bulunmaktadır. Örneğin sahâbeden biri, Hz. Peygamber'e, "Şayet bir kâfirle karşılaşıp onunla savaşırsam ve bu kişi kılıcıyla elimi kesip koparsa, sonra kaçıp bir ağaca sığınsa ve 'Ben Müslüman oldum' dese bu durumda onu öldürebilir miyim?" diye bir soru sormuş; Hz. Peygamber de "Hayır, onu öldürme!" diye cevap vermiştir. ${ }^{21}$ Ancak gerek Kur'ân-1 Kerîm'de gerek hadislerde yer alan farazî nitelikli meseleler günlük hayatta karşılaşılabilir olağan meselelerden oluşmaktadır.

Hz. Peygamber'in vefatıyla birlikte vahye dayalı teşrî son bulmuş ve sahâbe müçtehitleri, hakkında doğrudan nass veya rivayet bulunmayan meseleler hakkında içtihatta bulunmak zorunda kalmışlardır. Hz. Peygamber döneminde başlayıp dört halife ve sonrasında artarak devam eden fetihler neticesinde İslam coğrafyasına farklı kültür ve geleneklere sahip toplumların girmesiyle birlikte, hakkında içtihat edilmesi gereken hukukî hadiseler artmıştır. Ayrıca bu hadiseler, vukua geldikleri toplumların izlerini taşıdığından, daha girift bir yapıya bürünmüştür. Bu durum, içtihat yapılırken re'ye dayalı aklî yöntemlerin gelişmesini sağlamıştır. Böylece kökleri sahâbe dönemine dayanan ve hüküm ortaya çıkarmada nasslara ve rivayetlere yaklaşım farklılığını ifade eden "ehl-i re'y" ve "ehl-i hadîs" ana akımları ortaya çıkmıştır.

\footnotetext{
16 Osman Bayder, "Ebû Hanîfe'nin Kurucu İmam Olmasının Anlamı", Devirleri Aydınlatan Meş'ale İmam-ı A'zam Ulusal Sempozyum Tebliğler Kitabı. (Eskişehir: Osmangazi Üniversitesi Yayınları, 2015), 531.

${ }_{17}$ Yunus Apaydın, "Bir Muhafazakar Reycilik Teorisyeni: Ebu Hanîfe", İslami Araştırmalar Dergisi Ebu Hanife Özel Sayısı. 15/1-2 (2002), 147.

${ }^{18}$ Muhammed Ebû Zehre, Ebû Hanîfe; Hayâtuh ve 'Asruh - Ârâuh ve Fikhuh. (Kahire: Dâru'l-Fikri'l-'Arabî, 1976), 259.

${ }^{19}$ Nisâ: 4/102.

${ }^{20}$ Necmüddîn Süleymân b. Abdilkavî b. Abdilkerîm b. Saîd et-Tûfî el-Hanbelî, el-İşârâtü'l-îlâhiyye ile'l-Mebâhisi'l-Usûliyye. (Kahire: el-Fârûku'l-Hadîse li't-Tibâ'a ve'n-Neşr, 2002), 2: 42.

${ }^{21}$ Buhârî, "Meğâzî", 11; Müslim, "İmân”, 41; Ebû Dâvûd, "Cihâd”, 104). Hz. Peygamber'in farazî meselelere cevap verdiği ya da farklı amaçlarla bizzat kendisinin faraziyelere başvurduğunu gösteren bazı örnekler için bkz.: Buhârî, "Sayd ve Zebâih", 23; “Meğâzî", 11; Müslim, “Edâhî", 4; "İmâre”, 12; “İmân”, 41, 62; “Hacc”, 66; Tirmizî, "Fiten”, 30; Ebû Dâvûd, “Cihâd”, 104; "Menâsik", 19.
} 
Medine merkezli ehl-i hadîsin sahâbe ve tâbiûn neslinden hocalarının farazî meselelerin sorulmasına karşı çıktıkları ve bu meseleler hakkında içtihat etmekten kaçındıkları rivayet edilmektedir. Hz. Ömer, Zeyd b. Sâbit, Übeyy b. Ka'b, Ammâr b. Yâsir ve Abdullah b. Ömer'in vuku bulmamış hadiselerin sorulmasına yönelik negatif tutumları ${ }^{22}$, tabiûn dönemi ve sonrasında ehl-i hadîsin farazî meselelere yönelik olumsuz yaklaşımlarında ${ }^{23}$ etkili olduğu anlaşılmaktadır. Ayrıca ehli hadîs ekolüne mensup fukahânın, nassları ve rivayetleri öncelemeleri, bu iki kaynakta kendisine dair bir bilginin bulunduğu konularda mümkün olduğunca aklî yorumlardan kaçınmaları, vebal olarak gördükleri için re'y ile fetva vermekten mümkün olduğunca uzak durmaları gibi hususların da bu negatif tutumlarında rol oynadığı söylenebilir. ${ }^{24}$

Kûfe merkezli ehl-i re'yde ise Ebû Hanîfe'ye kadarki süreçte bütün fıkıh konularına uygulanan sistemli bir farazî fıkıh ameliyesi bulunmamaktadır. Bu süreçte İslam hukuku, soru-cevap ve vakıahüküm ekseninde bir seyre sahiptir. ${ }^{25}$ Ancak ehl-i re'y fukahânın farazî fıkıh faaliyetleri, ehl-i hadîse göre daha yoğundur. Bunu farklı nedenlerle açıklama imkânı bulunmaktadır. Kûfe'nin de içinde bulunduğu Irak bölgesi birçok kültür ve medeniyete ev sahipliği yapmıştır. Demografik çeşitliliğe sahip bölge olması cihetiyle Irak'ta vukua gelen ve çoğunlukla nass ve rivayetlerin doğrudan kapsamına girmediği hadiselerin fıkhî çözümünde, bölge fukahâsı, re'y ile içtihada daha çok ihtiyaç duymuştur. Ayrıca bölgede, farklı düşüncelere sahip İslâmî fırkaların bulunması, fırkalar arası tartışmaların yoğunlaşmasında etkili olmuştur. Hadis uydurma faaliyetleri de bölgenin ciddi problemleri arasındadır. Bu nedenle Kûfe ehl-i re'y fakîhleri, fıkıh meselelerinin çözümlerinde, farklı görüşlere karşı tartışmalarda ve rivayetleri değerlendirmede aklî yöntemlerden biri olan faraziyelerden istifade etmişlerdir. Aslında re'ye başvurmalarındaki neredeyse bütün etkenlerin, farazî fıkha başvurmalarında da rol oynadığını söyleyebiliriz.

Ebû Hanîfe'nin mensubu olduğu Kûfe ilim geleneğinden bazı önemli şahsiyetlerin farazî fıkıh temayüllerini kısaca açılamak yerinde olacaktır.

Kûfe ehl-i re'y ekolünün tâbiûn neslinden hocası Alkame b. Kays (ö. 62/682), farazî meseleleri fıkıh eğitiminde bir yöntem olarak kullanmış ve bu yönde tavsiyelerde bulunmuştur. Öğrencisi İbrâhîm en-Nehaî (ö. 96/714), ferâiz ilmini nasıl öğrenebileceğini sorduğunda Alkame, "Ferâizi öğrenmek istiyorsan komşularını öldür, miraslarını paylaştır" demiştir. ${ }^{26}$ Alkame'nin ifade etmek istediği şey, ferâiz gibi fıkhın matematiğe dayalı karmaşık bir konusunda ancak gerçekte vuku bulmamış farazî meseleler üzerinde alıştırmalar yapılarak yetkinlik kazanılabileceğidir.

Ebû Hanîfe'nin hocası Hammâd'tan (ö. 120/738) da Kûfe ehl-i re'y geleneğinde farazî metodun nesilden nesile kullanılagelen bir yöntem olduğunu gösteren ifadeler nakledilmiştir. Hammâd, "Nehaî’ye bir şey sorduğumda cevap verir, anlamadığımı hissettiğinde ise örneklere başvurur, kıyâslar yaparak anlamamı sağlardı" der ve Nehâî'nin bu yöntemi Alkame'den öğrendiğini söyler. ${ }^{27}$ Buna göre Nehaî'nin, farazîyeler üzerine kurulu kıyâs uygulamasını, farklı olaylar ve örnekler

\footnotetext{
${ }^{22}$ Ebû Muahmmed Abdullah b. Abdirrahmân ed-Dârimî, Sünenu'd-Dârimî, thk. Hüseyn Selîm Esed ed-Dârânî, (Riyâd: Dâru'lMuğnî li'n-Neşri ve't-Tevzî‘', 1420), 1: 242, 244.

${ }^{23}$ Hatîb el-Bağdâdî, el-Fakîh ve'l-Mütefakkih. thk. 'Âdil b. Yûsuf el-'Azâzî, (Riyâd: Dâru İbni'l-Cevzî, 1996), $2: 12$.

${ }^{24}$ Medine merkezli ehli hadis düşüncesinin farazî fıkha bakışlarıyla ilgi detaylı bilgi için bkz.: Halil Kılıç, "İmâm Mâlik'in Hukuk Düşüncesinde Farazî Fıkıh", Din ve Bilim - Muş Alparslan Üniversitesi İslami İlimler Fakültesi Dergisi. 3 / 2 (Aralık 2020), 126-133.

${ }^{25}$ Ahmet Yaman, Halit Çalış, İslâm Hukukuna Giriş. (İstanbul: İFAV yay., 2014), 86.

${ }^{26}$ Hatîb el-Bağdâdî, el-Fakîh ve'l-Mütefakkih, 2: 261-262.

${ }^{27}$ Hatîb el-Bağdâdî, el-Fakîh ve'l-Mütefakkih, 2: 261.
} 
arasında karşılaştırma yapmak suretiyle pedagojik amaçla kullandığı rahatlıkla söylenebilir. ${ }^{28}$ Buradaki kıyâs uygulamasından kasıt, sonraları formüle edilmiş analojik bir işlem olup meseleler arası benzerlik tesisidir. ${ }^{29}$

Alkame ve Nehaî'den sonra Kûfe ehl-i re'y halkasının başına geçen Hammâd'ın, farazî fikhı daha etkin bir biçimde kullandığı anlaşılmaktadır. Nitekim Kûfe'de ehl-i hadîsin önde gelen temsilcilerinden olan Şa'bî (ö. 104/722), Hammâd ve ashâbının fıkıh müzakerelerinde kıyâs eksenli farazî meseleleri kullanmalarından rahatsız olmuştur. Şâ‘bî, "Vallahi onlar, beni mescide (Kûfe Mescidi) gitmekten soğuttu. Öyle ki (gözümde) mescit, evimin çöplügüunden daha kötü oldu" şeklindeki ifadeleriyle bu faaliyete olan tepkisini dile getirmiştir. Şa‘bî’ye onların kim olduğu sorulduğunda, "Eraeytiyyûn/Eraeyteciler" diye cevap vermiştir. ${ }^{30}$ Şa'bî'nin, Hammâd ve ashâbını "eraeytiyyûn" şeklinde isimlendirmesinin nedeni, sordukları farazî meselelerin başında "peki şuna ne dersin?" anlamina gelen "eraeyte" kipini kullanmalarıdır. Nitekim onlar bu tür sorular sorarak, aklî istidlâle ve kişisel görüşlere başvurmuşlardır. ${ }^{31}$ "Eraeyte" kipiyle sorulan meseleler, yukarıda zikrettiğimiz kıyâs uygulamasının bir parçasıdır. Bu bakımdan "eraeyte" kipi, bu tür bir kıyâs işleminde muhatabı, farklı olayların ortak yönlerini tespit ederek benzerliklerini düşünmeye davet amacıyla kullanılmaktadır. ${ }^{32}$ Ehl-i re'y, bazen de farazî meseleler üzerine kurulu bu türden bir kıyâsı, haber-i vâhid gibi sıhhatinden şüphe duydukları rivayetlerin naklî ve aklî tutarlılığını test etmekte kullanmışlardır. ${ }^{33}$ Genel olarak ehl-i re'yin bu türden kıyâslara başvurma eğilimleri olsa da Hammâd'ın bu işlemi daha yoğun bir şekilde kullandığını gösteren rivayete göre İmam Mâlik, onun hakkında "Bizim nazarımızda Basralılar, Iraklılardı ve onlar iyi insanlardı. Kûfe'de ise Alkame, Esved ve Şüreyh gibi adamlar vardı. Ta ki Hammâd diye biri ortaya çıtı ve dine itirazda bulunup re'yi ile hüküm verdi" demiştir. ${ }^{34}$ Bu husus, sonraları kıyâsa muhalif haber-i vâhidle amele yönelik tartışmalar olarak literatürdeki yerini alacaktır. Farazî meselelerin bu amaçla kullanımını, Ebû Hanîfe'den yapacağımız nakillerde de göreceğiz.

Kûfe ehl-i re'y hakkında kısa bir özetleme yapmak gerekirse şunları ifade edebiliriz: Ebû Hanîfe'ye kadarki süreçte Medine ehl-i hadîs çevrelerinde farazî fıkıh eksenli bir telif bulunmadığı gibi Kûfelilerde de bulunmamaktadır. Küfelîler farazî meselelerle daha fazla ilgilenmişlerdir. Ancak bu ilgi, yaşadıkları bölgedeki karşılaşılan hadiselerin Hicâz'a göre daha farklı yapıda oluşundan ya da farazî yöntemin aklî istidlâl aracı olmasından kaynaklanmaktadır.

\section{Ebû Hanîfe'ye Göre Farazî Fıkhın Meşruiyeti}

İslam hukuk tarihinde farazî fıkhın ilk defa kim tarafından kullanıldığına yönelik iki görüş bulunmaktadır. Son dönem İslam hukuk araştırmacılarından Hacevî, farazî fıkhın ilk defa Ebû Hanîfe

\footnotetext{
28 Özen, Şükrü, İslam Hukuk Düşüncesinin Aklileşme Süreci Başlangıçtan Hicrî IV. Asrın Ortalarına Kadar. (İstanbul: Marmara Üniversitesi, Sosyal Bilimler Enstitüsü, Doktora tezi, 1995), 201.

${ }^{29}$ Eyyüp Said Kaya, Mezheplerin Teşekkülünden Sonra Fikhî İstidlâl. (İstanbul: Marmara Üniversitesi, Sosyal Bilimler Enstitüsü, Doktora Tezi, 2001), 107.

${ }^{30}$ Ebû İshâk İbrâhim b. Mûsâ el- eş-Şâtıbî, el-Muvâfekât fî Usûli'ş-Şerî́a. thk.: İbrâhîm Ramadân, (Beyrut: Dâru'1-Ma'rife, 2010), 4: 661.

${ }^{31}$ Kadir Gürler, Ehl-i hadîsin Düşünce Yapısı -illk Dönem Ehl-i hadîs Örneği. Bursa: Emin Yay., 2007), 123-124

32 Nâdiye Muhammed Şerîf el-Ömerî, Neş'etü'l-Kıyâsi'l-Usûlî ve Tetavvüruhu: Dirâse fì 'ílmi Usûli'l-Fıkh. (Cize: Hicr li't-Tibâ'a ve'n-Neşr, 1987, 8.

${ }^{33}$ Joseph Schacht, The Origins of Muhammadan Jurisprudence. (Oxford: The Clarendon Press, 1975), 110.

34 İbn Asâkir Ebü'l-Kâsım Ali b. Hasan ed-Dımaşkî, Tarîhu Dımaşk. (Beyrut: Dâru'l-Fikr, 2000), 10: 295.
} 
tarafından ihdas edildiği görüşündedir. ${ }^{35}$ Muhammed Ebû Zehre ise farazî fıkhın Ebû Hanîfe'den önce Kûfe ehl-i re'y fakihleri tarafından kullanıldığı, Ebû Hanîfe'nin seleflerinden devraldığı bu faaliyeti bütün fıkıh konularına uygulayarak sistemleştirdiği kanaatindedir. ${ }^{36}$ Ebû Zehre'nin, farazî fıkhı sistemleştiren kişinin Ebû Hanîfe olduğuna yönelik görüşü daha isabetli gözükmektedir. Ancak bu tarz fıkıh anlayışının ilk defa Kûfeliler tarafından kullanıldığına yönelik görüşüne katılmak mümkün değildir. Zira daha önce de ifade ettiğimiz üzere gerek Kur'an-1 Kerîm'de ve Sünnet'te gerekse sahâbe içtihatları içerisinde farazî fıkhın nüveleri görülmektedir. Ayrıca varsayıma başvurmak ilmî bir gereklilik olduğu gibi fıtrî bir olgudur da. Varsayımları ve ihtimalleri düşünerek kısa ya da uzun vadeli gelecek planlaması yapmak, hayatımızın bir parçasıdır. Ayrıca "farazîlik" hukukun doğasında ve yapısında bulunan bir özelliktir. Hukuk normlarına konu olan davranışlar farazî nitelikli olup somut bir olguya ya da hadiseye denk düşmez. ${ }^{37}$ Binaenaleyh fikıh ilminde varsayımlara başvurmanın ilk defa Ebû Hanîfe'yle başladığını iddia etmek bu hususlara aykırılık teşkil eder.

Ebû Hanîfe'nin farazî fıkhın meşruiyetine ve gerekliliğine yönelik bakışını ortaya koyan bir rivayet şöyledir: Kûfe'ye gelen Katâde (ö. 117/735), kendisini ziyaret için toplanan kalabalığa, helâl ve haramla ilgi sorulacak her soruya cevap vereceğini söyler. Bunun üzerine Ebû Hanîfe "Senelerce kayıp (mefkûd) bir adamın karısı, kocasının öldügüne kanaat getirerek bir başkasıyla evlenir. Kayıp koca dönerse, kadının (ikinci eşinden aldığı) mehir ne olacak?" şeklinde bir mesele sorar. Katâde, meselenin gerçekte yaşanıp yaşanmadığını sorar ve gerçekleşmediğini öğrenince Ebû Hanîfe'ye, "Gerçekleşmemiş bir şeyi niye soruyorsun?" diye çıkışır. Bunun üzerine Ebû Hanîfe, "Bizler, henüz başımıza gelmemişken belaya hazırlıklı olmalıyız. Böylece bela gerçekleştiğinde ona müdahale etmesini ve ondan kurtulmasını da bilmiş oluruz" diye cevap verir. ${ }^{38}$ Ebû Hanîfe'nin bu cevabı, gelecekte vuku bulacak hadiselere hazır hüküm bulundurma gayesiyle farazî meselelerin hükmünü araştırmanın meşruluğuna delildir. Farazî fıkhın bu işlevi, hukukun; toplumsal hayatı şekillendirmek, hakların çatıştığı bir ortamda kaosu önleyerek en kısa sürede müdahalede bulunmak ve adaletin teminini sağlamak gibi amaçlarına uyumluluk arz eder.

Farazî fıkhı, bu gayeye hizmet eden bir yöntem olarak gören Ebû Hanîfe, bütün fıkıh konularında teferruatlı meseleler vazetmiştir. Cüveynî (ö. 478/1085), bunu ilk yapan kişinin Ebû Hanîfe olduğunu şöyle ifade eder: "Sahâbe ve tâbiûndan sonra Ebû Hanîfe geldi ve fıkıh meselelerini teferruatlandırdı ve sayılamayacak kadar furû meseleleri üretti. O, akıllıların hayrete düşeceği derecede kılı kırk yararcasına gaybı aydınlatacak dakik meseleler vazetti ve ömrünü bu uğurda tüketti."39 Bezzâzî (ö. 827/1424) de "Ebû Hanîfe, (fıkıh meselelerini) öyle bir tefrî ve tedvin etti ki önemli bir olay onun müdevvenâtının dışında kalmaz. Gerçekleşebilecek her olayın cevabı bu müdevvenatta yazılıdır." demektedir. ${ }^{40}$ Ebû Hanîfe'nin üretmiş olduğu meselelerin sayısıyla ilgili

\footnotetext{
${ }^{35}$ Muhammed b. Hasan el-Hacevî, el-Fikru's-Sâmî fî Tarîhi'l-Fıkhi'l-İslâmî. (Beyrut: Dâru'l-Kutubi'l-İlmiyye, 1995), 1: 419.

${ }^{36}$ Ebû Zehre, Ebû Hanîfe, 259.

${ }^{37}$ Yasemin Işıktaç, Hukuk Normunun Mantıksal Analiz ve Uygulaması. (İstanbul: Filiz Kitabevi, 2004$), 98$.

${ }^{38}$ Ebû Bekr Ahmed b. Ali b. Sâbit el-Hatîb el-Bağdâdî, Tarîhu Medîneti's-Selâm. thk. Beşşâr Ma'rûf, (Beyrut: Dâru'l-Ğarbi'l-İslâmî, 2001), 15: 477.

39 İmâmü'l-Haremeyn Ebü'l-Me'âlî Ruknüddîn Abdülmelik b. Abdullâh el-Cüveynî, Muğ̣̂sü̈l-Halk fì Tercîhi'l-Kavli'l-Hakk. (Misır: el-Matba‘atü'l-Misriyye, 1934), 18.

${ }^{40}$ Hâfızuddîn b. Muhammed el-Kerderî el- Bezzâzî, Menâkıbu Ebî Hanîfe. (Beyrut: Dâru'l-Kitâbi'l-'Arabî, 1981$), 34$.
} 
altmış bin, üç yüz bin, beş yüz bin gibi sayılar verilmekle ${ }^{41}$ birlikte Bâbertî (ö. 786/1384), Ebû Hanîfe ve ashâbının bir milyon yüz yetmiş bin küsur mesele vazettiklerini ifade eder. ${ }^{42}$

Ebû Hanîfe, kendisine sorulan fikhî meselelere cevap vermede çekingen bir tutuma sahip olmaması nedeniyle sorulan farazî meselelere de olumsuz bir tavır sergilememiştir. Bu yapısı nedeniyle bazen eleştirilmiştir. Sufyân b. Uyeyne (ö. 198/814), Horasan'dan gelen birinin Ebû Hanîfe'ye yüz bin mesele getirdiğini, Ebû Hanîfe'nin de hiç çekinmeden "Hadi getir" dediğini ifade eder. İbn Uyeyne, kendilerine soru sorulan sahâbenin, soruyu birbirlerine havale ettiklerini ifade ederek Ebû Hanîfe'yi cüretkâr davranmakla suçlar. ${ }^{43}$ Bu rivayetteki meselelerin sayısı abartıl1 ${ }^{44}$ olsa da Ebû Hanîfe İslâm coğrafyasının farklı bölgelerinden gelen meselelerin kendisine sorulduğunu ve onun fıkhî meseleleri vakıa ve farazî şeklinde bir ayrıma tabi tutmadığını göstermesi açısından dikkate değerdir.

\section{Ebû Hanîfe'nin Farazî Fıkhı Kullanmasında Etkili Faktörler}

Ebû Haniffe'nin farazî fıkhı aktif bir biçimde kullanmasında yetiştiği ilmî ve sosyal çevre belki de en önemli faktörlerin başında gelir. Irak birçok medeniyete, dinî ve etnik gruba ev sahipliği yapmıştır. ${ }^{45}$ Farklı örf, gelenek ve kültürlerin bulunması karşılaşılan hâdiselerin de aynı oranda çeşitliliğinde rol oynamıştır. ${ }^{46}$ Müslümanlar tarafından fethedildiği andan itibaren bölge, bu yönüyle meşhurdur. Irak bölgesinde vuku bulmuş hadiselerin giriftliğini gösteren bir rivayete göre Abdullah b. Ömer, "Siz Iraklılar bizlere içinden çıkılması zor meselelerle geliyorsunuz" demiştir. ${ }^{47}$ Hâdiselerin girift yapısı ile çeşitliliği ise re'ye ve dolayısıyla aklî istidlâl yöntemlerine daha çok başvurmayı gerektirmiştir. Farazî meseleler ekseninde meseleler arası paralellik ve benzerlik kurmak da bu yöntemlerden biridir.

Ayrıca Irak bölgesi, ilmî faaliyetler açısından da diğer İslâm coğrafyalarına göre oldukça zengin bir ilim merkezidir. Fethedilmeden önce bu bölgede felsefe, mantık, tıp, astronomi, matematik, hendese vb. ilimlerin tedvininin gerçekleşmiş olduğu bilinmektedir. ${ }^{48}$ İslâm dünyasında ilk tercüme faaliyetlerinin bu bölgede yoğunlaşmış olması da bunun bir göstergesidir. Tercüme faaliyetleriyle birlikte bu ilimlerin Müslümanlara geçişi, İslamî ilimlerin tedvin ve tasnifine ön ayak olduğu söylenebilir. Nitekim Hacevî (ö. 1956), Müslüman âlimlerin diğer toplumlara ait birikime vukufiyetlerini, fıkhın dağınık bilgi ve içtihatlardan müteşekkil bir yapıdan çıkıp sistemleşmesini sağlayan faktörlerden biri olduğunu söyler. ${ }^{49}$ Takiyyuddîn en-Nebhânî (ö. 1977) ise Müslümanların bu birikimlerden yola çıkarak ilimlerin telif ve tanzimini öğrenmiş olmalarının bir etkilenme değil yararlanma olduğunu söylemektedir. Çünkü ilimlerin telif ve tanzim tarzı, herhangi bir kültüre, dine vb. oluşumlara özel olmayıp insanlığın ortak ürünüdür. ${ }^{50}$ Böyle bir ortamda yetişen Ebû Hanîfe'nin,

\footnotetext{
${ }^{41}$ Hacevî, el-Fikru's-Sâmî fì Tarîhi'l-Fıkhi'l-İslâmî, 419.

${ }^{42}$ Ekmelüddîn Muhammed b. Muhammed b. Mahmûd b. Ahmed el-Bâbertî, el-'Inâye Şerhu'l-Hidâye. (Beyrut: Dârü'l-Kütübi'lİlmiyye, 2003), 1: 6.

${ }^{43}$ Hatîb el-Bağdâdî, Tarîhu Medîneti's-Selâm, 15: 542.

${ }^{44}$ Muhammed Zahid Kevserî, Te'nîbü'l-Hatîb 'alâ mâ Sâkahu fî Tercemeti Ebî Hanîfe mine'l-Ekâzî̉b. (b.y.: y.y., 1990$), 194$.

${ }^{45}$ Bedir, Ebu Hanife, 65;

${ }^{46}$ Ebû Zehre, Ebû Hanîfe, 94; Köse, İslam Hukukuna Giriş, 159.

${ }^{47}$ Ebû Yûsuf Ya'kûb b. Süfyân el-Fesevî, el-Ma'rifetü ve't-Tarîh. (Beyrut: Müessesetü'r-Risâle, 1981), 2: 759.

${ }^{48}$ Gürkan Dağbaşı, “Abbasi Dönemi Çeviri Faaliyetleri”, Eski Yeni Anadolu İlahiyat Akademisi Araştırma Dergisi. 27 (2013), 180184.

${ }^{49}$ Hacevî, el-Fikru's-Sâmî fì Tarîhi'l-Fıkhi'l-İslâmî, 1: 400.

${ }^{50}$ Takıyyuddîn en-Nebhânî, eş-Şahsıyyetü'l-İslâmiyye. (Beyrut: Dâru'l-Ümme li't-Tıbâ‘a ve'n-Neşr, 2003), 1: 284.
} 
fıkıh ilmini, konu ve sınırları belli bir sistematiğe kavuşturmasında farazî meselelerden istifade etmesi kaçınılmaz olmuştur. Zira bir ilim dalının teşekkül ve tanziminde yalnızca vakıalarla ve mevcut birikimle yetinmek kifayet etmez. Bunun için dağınık halde bulunan meselelerin belli bir örüntüye ve aklî bütünlüğe bürünmesi, varsayımlarla desteklenmesi ve farazî meselelerle kopukluğun giderilmesi gerekmektedir.

Ebû Hanîfe'nin tartışmacı kişiliği de farazî fıkha yönelmesini sağlayan faktörlerden biridir. O, fıkha yönelmeden önce kelâm ilmiyle iştigal etmiş ve kendisinin ifadesiyle aktarıldığına göre kelâm ilminde parmakla gösterilir bir seviyeye ulaşmıştır. ${ }^{51}$ Farklı İslâmî fırkaların doğduğu Irak bölgesi, cedel ve münazaraların yoğun olarak yaşandığı kelâm ilmi açısından da oldukça merkezî bir konumdadır. Ebû Hanîfe, fıkıh ilminde sıkça kullandığı münazara ve cedel üslubunu, kelâm ilmiyle iştigal ettiği gençlik döneminden almış olmalıdır. ${ }^{52}$ Onun, hocası Hammâd'la yapmış olduğu tartışmalarda bu yeteneğinin izlerini görmek mümkündür. Nitekim Hammâd, bir tartışma sonrasında Ebû Hanîfe'nin cedelî sorularından bıkkınlığını "Yeter artık ey Ebû Hanîfe! Kalbim daraldı" şeklinde ifade etmiştir..$^{53}$ Cedel ve münazara yapılırken tartışmacıların kendi görüşlerini ispat etmek ve karşı tarafın görüşünü çürütmek için varsayım önemli bir metottur. Muasırı İbn Ebî Leylâ (ö. 148/765) ile yaptığı şu münazarada, Ebû Hanîfe'nin farazî meseleleri kullandığı görülür: Halife Ebû Cafer elMansûr (ö. 754-775), İbn Ebî Leylâ ve Ebû Hanîfe'den maldaki ayıplardan satıcının sorumlu olup olmayacağı meselesini tartışmalarını ister. İbn Ebî Leylâ, alıcıya ayıpları teker teker göstermedikçe akit esnasında şart koşmuş olsa bile sorumluluğun satıcıdan kalkmayacağını savunmaktadır. Şartın geçerliliğini ve satıcının sorumlu tutulmayacağı görüşünde olan Ebû Hanîfe, "eraeyte" kipiyle başlayan faraziyeler getirerek şöyle der: Söyler misin? Şayet bir adam, cinsel organı kusurlu olan güzel bir cariyeyi satmak isterse, cariyenin avret yerini açıp bu kusuru alıcıya göstermesi gerekir mi? Söyler misin? Şayet Emîrulmü'minîn'in eşleri, erkeklik uzvu baraslı (alaca hastalığına yakalanmış) Habeşli bir kölelerini satmak isteseler, alıcıya bu kusuru gösterme zorunlulukları var mı Bu tartışmayı nakleden Serahsî (ö. 483/1090), Ebû Hanîfe'nin buna benzer ayıp sınırlarını zorlayan farazî meselelerle İbn Ebî Leylâ'yı susturduğunu ve İbn Ebî Leylâ'nın kusurların gösterilmesine yönelik görüşünden vazgeçerek maldaki kusurların açıklanmasını yeterli gördüğünü belirtir. ${ }^{54}$

\section{Farazî Fıkıh Özelinde Ebû Hanîfe'ye Yöneltilen Eleştiriler}

Ebû Hanîfe, farazî meseleler üretip fikhî faaliyetlerini bunlar üzerinde icra etmesi nedeniyle bazı eleştirilere maruz kalmıştır. Bu eleştirileri, biri fıkıh konularını detaylandırarak gerçekleşmemiş vakalar üzerinde hüküm beyan etmesi, diğeri aklî bir yöntem olarak farazî meseleleri tartı̧malarda ve rivayetleri değerlendirmede kullanması olmak üzere iki grupta değerlendirmek mümkündür.

Daha önce ifade ettiğimiz üzere Ebû Hanîfe'den önce de farazî meseleler fikhî mesailde kullanılmıştır. Ancak önceki nesillerden aktarılan meseleleri de kapsayan sistematik ve doktriner bir farazî fıkıh anlayışını geliştiren kişi Ebû Haniffe' dir. Ona, farazî mesele üretirken aşırıya kaçtığı öyle ki gerçek hayattan kopuk asla gerçekleşmeyecek meseleleri varsaydığı, sünneti ve kendinden öncekilere ait içtihatları hiçe saydığı yönünde eleştiriler yöneltilmiştir. Rivayete göre Şâfiî, Rakabe b. Maskala, Hafs b. Ğiyâs (ö. 194/810) ve Kays b. Rabî” gibi âlimlerin, "Ebû Hanîfe, vuku bulmuş meseleler

\footnotetext{
${ }^{51}$ Bezzâzî, Menâkıbu Ebî Hanîfe, 2: 135.

52 Muhammed Mustafa eş-Şelebî, el-Medhal fi'l-Fıkhi'l-İslâmî. (Beyrut: ed-Daru'l-Câmi'iyye, 1985), 134.

${ }^{53}$ Muvaffak b. Ahmed el-Mekkî, Menâkıbu Ebî Hanîfe. (Beyrut: Dâru'l-Kitâbi'l-'Arabî, 1981), 1: 51-53.

${ }^{54}$ Serahsî, el-Mebsût, 30: 133.
} 
hakkında insanların en cahili, henüz vuku bulmamış meseleler konusunda ise en âlimidir." dedikleri rivayet edilmektedir. ${ }^{55} \mathrm{Bu}$ rivayetin son kısmı bazı kaynaklarda "sünnetin en câhili" şeklindedir. ${ }^{56}$

Ebû Haniffe'yi eleştirenler arasında farazî fıkıh açısından oldukça velût bir şahsiyet olan İmâm Şâfiî̀nin bulunması ilginçtir. Nitekim Şâfiî, el-Ümm adlı eserinde birçok farazî meseleyi ele almaktadır. Aynı zamanda Şâfiî, Şeybânî gibi ehl-i re'y fakîhleriyle farazî meseleleri içeren tartışmalara girmiştir. Muhtemelen Şâfiî, farazî fıkıh nedeniyle Ebû Hanîfe'yi eleştirdiği ifadelerini, henüz kendine has müstakil bir fıkıh anlayışı geliştirmediği ve farazî fıkıh karşıtı tavırlarıyla bilinen Hicâz ehl-i hadîsin destekleyicisi olduğu gençlik yıllarında serdetmiştir. O, Irak'a gittikten sonra bu eleştirisinden vazgeçmiş olmalıdır. ${ }^{57}$ Nitekim Hanefî fakîhi Bâbertî, Şâfiî'nin, insanların fıkıhta Ebû Hanîfe'nin iyali olduğuna yönelik meşhur ifadesini bu bağlamda değerlendirir. Bâbertî'ye göre Şâfiî́nin bu ifadeyle, Ebû Hanîfe'nin farazî meseleler üzerinden icra ettiği fıkıh faaliyetlerini kastetmiş olması kuvvetle muhtemeldir. ${ }^{58}$

Hicrî ikinci asırdan sonra Ebû Hanîfe hakkında yapılan bu eleştiriler, yerini övgülere bırakmıştır. Nitekim bu evrede farazî fıkha yönelik olumsuz bakış açısı zayıflamış, teferruatlı farazî meseleler artık Mâlikî ve Şâfiîler tarafından kullanılmış ve bu meseleleri içeren eserler kaleme alınmıştır. Ebû Hanîfe'ye farazî fıkıhla ilgili yapılan övgülerden iki tanesi şöyledir:

Yahyâ b. Eksem (ö. 242/857); Ebû Hanîfe ve ashâbının teferruatlı meselelerle insanları meşgul ederek usulden (aslî kaynaklar olan Kitâb ve Sünnet'ten) oyaladığını, şayet insanlara usûlü anlatıp açıklasalardı bu meselelere gerek kalmayacağını söyler. İbn-i Eksem'e göre kendisine mesele sorulan fakîh, bu usûllere başvurarak meselenin hükmünü istinbât edebilir. Bu eleştiriyi işiten Hasan b. Hammâd Seccâde (ö.241/855), İbn-i Eksem'e "Sana onların teferruatından bir mesele sorayım da dediğin gibi yapıp cevabını ver de göreyim" der ve şöyle bir soru yöneltir: "Bir adam ölür, ardında miras olarak bir ev, vâris olarak da karısı ve bir oğlu kalır. Bu ev vârislere nasıl paylaştırılır?" İbn-i Eksem, "karısı 1/8'i alır, geriye kalan da oğulundur" der. Seccâde, meseleyi biraz daha giriftleştirir ve şöyle sorar: "Karı ve oğul bu evi bir akitle bir miktar para karşılığında bir adama satar. Daha sonra başka bir adam ortaya çıkar ve oğula düşen payın içinden evin yarı hissesinde hak sahibi olur. Evi satın almış olan kişi, karı ve oğulun her birinden hangi oranda malını tazmin eder?" İbn-i Eksem, birkaç cevap verir ancak Seccâde, her cevabın sonunda yanlış cevap verdiğini söyler ve İbn-i Eksem'e hatasını kabul ettirir. Seccâde, "Kâdı hazretleri fıkıh ilmindeki derin bilgisine rağmen bir mesele hakkında üç hatalı cevaba karşılık doğru bir cevap veremiyor. İnsanları bu meselelerin hükümlerinden kurtaran bir kişiyi ne demeye kötülüyorsun?" der ve İbn-i Eksem susar. ${ }^{59}$

Şâfiî mezhebinin gelişiminde önemli bir role sahip olan İbn Süreyc (ö. 306/918) de Ebû Hanîfe'yi kötüleyen birine “Ümmet, soru ve cevaplardan müteşekkil bir ilim olan fıkhın dörtte üçlük bölümünü Ebû Hanîfe'ye borçludur. Çünkü Ebû Hanîfe, meseleler ürettiğinden ilmin yarısı onun eseridir. Sonra o, bu meselelere cevaplar da vermiştir. Bu cevapların tamamında hatalı hüküm vermediğine göre,

\footnotetext{
${ }^{55}$ Hatîb, Tarîhu Medîneti's-Selâm, 15/558.

${ }^{56}$ Ebû Bekr Ahmed b. Huseyn b. Ali el-Beyhakî, Menâkıbü'ş-Şâfî̀. (Kahire: Dârü't-Türâs, Kâhire, 1970), 1: 128.

${ }^{57}$ Kılıç, “İmâm Şâfiî̀'de Farazî Fıkıh", 41. İmâm Şâfiî̀'nin farazî fıkıh anlayışı ile ilgili geniş bilgi için mezkûr çalışmaya bakınız.

58 Ekmelüddîn Muhammed b. Muhammed b. Mahmûd b. Ahmed el-Bâbertî, en-Nüketü'z-Zarîfe fî Tercîhi Mezhebi Ebî Hanîfe. (Riyad: Câmi'atü'l-Melik Sü'ûd, 1997), 34.

59 İbn Ebi'l-'Avvâm, Ebü'l-Kasım Abdullah b. Muhammed b. Ahmed b. Yahya b. el-Hâris, Fedâilü Ebî Hanîfe ve Ahbâruhîu ve Menâkıbühü. (Mekke: el-Mektebetü'l-İmdâdiyye, 2010), 374.
} 
verdiği cevaplarla birlikte ilmin dörtte üçü ona aittir. Geriye kalan çeyrek payda da diğer âlimlere ortaktır" şeklinde cevap vererek Ebû Hanîfe' yi övgüyle yâd etmiştir. ${ }^{60}$

Ebû Hanîfe'nin farazî meseleler hususunda eleştirildiği bir diğer husus, rivayetlerin aklî ölçütlere uygunluğunu değerlendirme sadedinde farazî meseleleri kullanmasıdır. Çağdaşı Süfyân b. Uyeyne, Ebû Hanîfe'nin, Hz. Peygamber'den rivayet edilen hadisleri örneklerle (darb-1 mesel) test ettiğini söyleyerek eleştiride bulunur. ${ }^{61}$ İbn Abdilberr (ö. 463/1071) de ehl-i hadîsin, Ebû Hanîfe'yi kötülerken aşırıya kaçmalarının temel sebebinin, rivayetin sened açısından sahih olması durumunda kıyâs ve aklî çıkarımların (nazar) geçerli olmayacağı yönündeki çoğunluğa ait görüşe rağmen, onun, rivayetlere re'y ve kıyâsı dâhil etmesi ve bunları nasların değerlendirilmesinde dikkate alması olduğunu ifade eder. ${ }^{62}$

Ebû Hanîfe'ye yöneltilen bu eleştiriye neden olan iki mesele şöyledir: Ebû Hanîfe, ölü bir toprağı imar ve ziraata elverişli hale getirme (ihyâü'l-mevât) meselesinde devlet başkanının iznini şart koşmaktadır. Ona göre devlet başkanının izin vermesi halinde, ihyâ edilen ölü toprak onu ihyâ edene aittir. Ancak ihyâ, devlet başkanından izinsiz gerçekleşmişse toprağın mülkiyeti ihyâ edene geçmez. Bu durumda devlet başkanı isterse toprağı onu ihyâ edenden alıp uygun gördüğü şekilde kullanabilir. Ebû Yûsuf (ö. 182/798), "Kim, ölü bir toprağı ihyâ ederse o toprak ona aittir"63 hadisinde devlet başkanının izni şart koşulmamasına rağmen Ebû Hanîfe'nin bu görüşte olmasının nedenini şöyle açılar: "Ebû Hanîfe bu konuda şöyle akıl yürütür: 'Söyler misin? Şayet iki adam gelip aynı toprağ1 ihyâ etmeye yeltense ve birbirlerine bu hususta engel olsalar, bu ihyâda hangisi daha haklıdır? Yine söyler misin? Şayet bir adam, başkasının avlusunun sınırlarında bulunan ölü bir toprağı ihyâ etmekte ısrar ederse ve avlu sahibi bu adama 'İhyâ etme! Bu bölge benim avlumun içerisinde yer aldığı için bana zarar verirsin' derse ne olacak?' İşte Ebû Hanîfe, insanlar arasında çıkacak muhtemel tartışmaları öngörmüş, bunu engellemek için ölü toprağın ihyâsını devlet başkanının iznine bağlamıştır. Ebû Yûsuf, Ebû Hanîfe'nin bu görüşünün, ilgili rivayeti aklî yöntem ve farazî meselelerle reddetmek anlamına geldiği yönündeki eleştirilere de cevap vermektedir. Ebû Yûsuf'a göre şayet Ebû Hanîfe, devlet başkanının izni olsun ya da olmasın ölü toprağın ihyasına karşı çıksaydı, ilgili rivayeti reddetmiş olurdu." 64

Bir diğer örneğimiz ise meclis muhayyerliği ile ilgilidir. Meclis muhayyerliğini düzenleyen hadiste Hz. Peygamber (s.a.v.), "Alıcı ve satıcı, ayrılmadıkları sürece muhayyerdirler" 65 buyurmuştur. İbn Abdilberr'in aktardığına göre Ebû Hanîfe, farazî meseleler getirerek bu hadisin aklî tutarlılığını ve uygulanabilirliğini test etmiştir. O, bu hadisi duyduğunda "Söyler misin? (أر أيت) Şayet alıcı ve satıc1 gemide, hapiste ya da tutsak olsalar nasıl ayrılacaklar? O zaman bunların alışverişi hiçbir zaman sahih olmayacaktır" ifadelerini kullanmıştır. Ehl-i hadîs, Ebû Hanîfe'nin, verdiği örneklerle hadisi, zâhir anlamı dışında bir anlama yorumladığını ve sahih olan hadise itirazda bulunduğunu iddia etmektedirler. ${ }^{66}$

\footnotetext{
${ }^{60}$ Serahsî, el-Mebsût, 1: 3; Bâbertî, en-Nüketü'z-Zarîfe, 34.

${ }^{61}$ Hatîb, Tarîhu Medîneti's-Selâm, 15: 530.

${ }^{2}$ İbn Abdilberr Ebû Ömer Yûsuf b. Abdillah el-Kurtubî, Câmi'u Beyâni'l-'ilmi ve Fadlihi. (Riyâd: Dâru İbni'l-Cevzî, 1994), 2: 1080.

${ }^{63}$ Ebû Dâvûd, "el-Harâc ve'l-İmâre ve'l-Fey', 37.

${ }^{64}$ Ebû Yûsuf, Ya'kûb b. İbrâhîm, Kitâbü'l-Harâc. (Beyrut: Dâru'l-Ma'rife, 1979), 64. Benzer meseleler için bkz.: Ebû Yûsuf, Kitâbü'l-Harâc, 175; Ebû Yûsuf, İhtilâfu Ebî Hanîfe ve İbn Ebî Leylâ. (Haydarâbâd: Matba'atü'l-Vefâ, 1358), 13, 35, 41-42, 72, 95, 101, 102-103.

${ }^{65}$ Buhârî, "Büyûu', 22; Müslim, "Büyû́'”, 11; Ebû Dâvûd, "Büyû'”, 54.

${ }^{66}$ İbn Abdilberr, el-İntikâ' fî Fedâili'l-Eimmeti's-Selâseti'l-Fukahâ. (Halep: Mektebetü'l-Metbû'âti'l-İslâmiyye, 1997$), 274$.
} 
Bu iki örnekte görüldüğü üzere Ebû Hanîfe, "eraeyte" kipini kullanarak aklî istidlâlde bulunmuştur. İhyâ etme meselesini ele alırken devlet başkanının izninin şart koşulmaması durumunda oluşabilecek muhtemel vakıaları varsaymış ve hükmün uygulanabilirliğini test etmiştir. $\mathrm{Bu}$ vakıaların gerçekleşmesi durumunda toplum içinde kargaşanın oluşabileceğini öngörerek, oluşacak olumsuzlukları bertaraf etmek için hükmü daha baştan revize yoluna gitmiştir. Aynı akıl yürütmeyi meclis muhayyerliği ile ilgili hadis için de yapmıştır.

\section{Ebû Hanîfe'de Bir Eğitim Metodu Olarak Faraziyeler}

Ebû Hanîfe, hocalığını yaptığı halkada faraziyeler üzere kurulu bir yöntem benimsemiştir. Kaynaklarda aktarıldığına göre bu halkada ele alınacak meseleyi Ebû Haniffe belirler ve öğrencilerinden tartışmalarını isterdi. Bu mesele gerçekte vuku bulmuş aktüel bir hâdise olabildiği gibi farazî olarak ortaya konmuş bir mesele de olabilirdi. İlgili mesele üzerine yapılan tartışmaların bazen günlerce sürdüğ̈̈67 dikkate alındığında meselenin yalnızca bir varyantıyla değil, detaylı varyasyonlarıyla diyalektik bir yöntemle ele alındığı anlaşılır. Zâhid el-Kevserî'nin aktardığına göre bu mecliste meseleler ele alınırken öncelikle Ebû Hanîfe, meselenin hükmü ile ilgili bir ihtimal ortaya atar ve bu ihtimali destekleyen delilleri sıralardı. Daha sonra ashâbına, bu ihtimale karşı koyabilecekleri bir delil bulunup bulunmadığını sorardı. Onların bu ihtimali kabul ettiklerini gördüğünde bu kez kendisi daha önce ortaya attığı ihtimali, muarız delillerle nakzederdi. Mecliste bulunanlar ikinci ihtimalin doğruluğuna kanaat getirdiklerinde Ebû Hanîfe, ikinci ihtimali de nakzederdi. Böylece doğru ihtimale varıncaya kadar meseleyle ilgili bütün ihtimalleri değerlendirirdi. ${ }^{68}$ Ebû Hanîfe, sonuç olarak ortaya çıkan hükümleri öğrencilerine kaydettirir; sonuçlanmadan yazmaya çalışanlara engel olurdu. ${ }^{69}$ Daha sonra bu değerlendirmelerden ortaya çıan ve mezhep usulünü oluşturan nihai hükümler üzerine fıkıh konularının teferruatı oluşturulurdu. Yani temel konularda oluşturulan asıllar üzerine spesifik ve detaylı meseleler inşa edilirdi. Özetleme/soyutlama ve genişletme/örneklendirme faaliyeti olarak da nitelenebilecek bu işlemler hakkında Nadr b. Şümeyl (ö. 204/820), “Ebû Hanîfe fikhı genişleterek, açıklayarak ve özetleyerek insanları uyandırana kadar onlar fikıhtan bihaber olup uykudaydılar" demektedir.70

Ebû Hanîfe'nin, hem usûl oluşturma hem de teferruatlandırma işlemlerinde varsayımlara başvurduğu açıktır. $\mathrm{O}$, bu işlemlerde varsayımlara başvurarak şerî hükümlerin mantıksal tutarlığını ortaya koymaya çalışmıştır. Bu gaye, onun ve temsil ettiği ehl-i re'y düşüncesinin temel özelliğidir. ${ }^{71}$ $\mathrm{Bu}$ işlemde her bir hükmün doğru olarak kabul edilmesi bir varsayımdan ibarettir. Doğrulamak ya da yanlışlamak üzere oluşturulmuş bu varsayımları, muvakkaten kabul edilmiş faraziyeler olarak görmek mümkündür. Ayrıca bu faaliyet tarzı, bir fıkıh konusuyla alakalı meselelerin uzanacağı noktaları tespit etmeye imkân tanır. ${ }^{72}$ Farazî meselelerin belirlenen asıllar üzerine inşası, asılların uygulanabilirliğini test etme aşaması olarak görülebilir.

Ebû Hanîfe'nin hocalığını yaptığı ilim halkasında öğrenciler aktif katılım sağlamışlardır. Öğrenciler de farazî meseleler inşa etmişler ve halkanın gündeminin belirlenmesinde rol oynamışlardır. Örneğin Şeybânî, halkaya henüz yeni katılmışken farazî bir mesele sormuştur. Sorulan

\footnotetext{
${ }^{67}$ Bezzâzî, Menâkıbu Ebî Hanîfe, 2: 57.

${ }^{68}$ Kevserî, Te'nîbü'l-Hatîb, 273.

${ }^{69}$ İbn Ebi'l-'Avvâm, Fedâilü Ebî Hanîfe, 341.

${ }^{70}$ Hatîb, Tarîhu Medîneti's-Selâm, 15: 473.

${ }^{71}$ Ahmed Hasan, İlk Dönem İslâm Hukuk Biliminin Gelişimi (Çev. Haluk Songur). (İstanbul: Rağbet Yayınları, 1999), 168.

${ }^{72}$ Kaya, Mezheplerin Teşekkülünden Sonra Fikhî İstidlâl, 111.
} 
meseleyi beğenen Ebû Hanîfe, Şeybânî'ye meselenin kendisi tarafından mı oluşturulduğunu yoksa başkasından işitmiş olduğu bir mesele mi olduğunu sormuştur. Şeybânî, meseleyi kendisinin oluşturduğunu söylediğinde Ebû Hanîfe, "Adamakıllı bir mesele sordun, halkamıza sık sık gel" diyerek memnuniyetini ifade etmiş ve taltifte bulunmuştur. ${ }^{73}$ Ayrıca Ebû Hanîfe, farazî meseleler üzerinden münazara yöntemini hukukçu formasyonu kazanmada gerekli görmektedir. Öğrencilerinin tartıştığı ve seslerinin yükseldiği ortamda onları engellemesini isteyen Süfyân b. Uyeyne'ye, “Onlara karışma! Çünkü fıkıhta yetkin olabilmeleri için bu yola başvurmaları gerekiyor"74 şeklinde cevap vermiş̧tir. Ebû Hanîfe'nin bu cevabı farazî fıkhın bir eğitim yöntemi olarak pedagojik amaçla kullanılmasına verdiği önemi izah eder mahiyettedir.

Ebû Hanîfe, talebelerin fıkıh eğitiminde istenilen seviyeye ulaşıp ulaşmadığını farazî meselelerle ölçmüştür. Bu hususu gösteren rivayete göre $\mathrm{o}$, fikhî yetkinliğe ulaştığını düşünerek halkasını terk eden ve kendisine ait bir ders halkası oluşturmak isteyen Ebû Yûsuf'a bir elçi göndermiştir. Elçiye, Ebû Yûsuf'a gidip icâre akdiyle ilgili "Bir kimse, bir dirhem karşılığında yıkaması için elbisesini çamaşırcıya (kassâr) verir. Bir müddet sonra elbisenin sahibi, çamaşırcıdan elbisesini ister ve çamaşırcı böyle bir akdi inkâr eder. Ancak bir müddet sonra çamaşırcı elbiseyi yıkanmış bir halde sahibine teslim eder. Bu durumda çamaşırcı yıkama ücretini hak eder mi?" diye sormasını ister ve verilecek "evet" ya da "hayır" cevapları için "hata ettin" demesini tembihler. Elçi, Ebû Yûsuf'a gidip soruyu sorar. Ebû Yûsuf, "evet" ve "hayır" şeklinde iki farklı cevap verir. Her iki cevap için de "Hata ettin" der. Bunun üzerine Ebû Yûsuf, soruyu Ebû Hanîfe'ye götürüp sorar. Ebû Hanîfe, "Çamaşırcı meselesi için mi geldin?" der. Ebû Yûsuf, "Evet, bana öğret" deyince Ebû Hanîfe, "Gasp ettikten sonra yıkamışsa çamaşırcı ücreti hak etmez. Çünkü kendisi için yıkamıştır. Çamaşırcı gasptan önce yıkamışsa yıkama ücretini hak eder. Çünkü bu durumda elbiseyi, sahibi için yıkamıştır" der. ${ }^{75}$ Görüldüğü üzere Ebû Hanîfe, farazî bir meseleyle öğrencisinin eksik yönlerini görmesini sağlamıştır. Aynı zamanda bu meselede görüleceği üzere farazî fıkıh, sorulan bir mesele detaylıca irdelenmeden mutlak anlamda verilecek bir hükmün ortaya çıkma riskini ortadan kaldıracaktır. Nitekim fukahâ, fetvâ ve kazâ ile ilgili problem olarak gördükleri bu durumu ele almışlardır. Hükmün değişkenlik göstereceği farklı ihtimalleri bulunan bir meseleye cevap verilirken bu ihtimallere yönelik hükümler detaylı ifade edilmelidir. ${ }^{76}$

\section{Ebû Hanîfe'de Farazî Fıkhın Sınırı}

Fıkıh mesaisinin her alanında farazî meseleleri etkin olarak kullanan Ebû Hanîfe' nin buna bazı sınırlar getirdiğini ondan gelen rivayetlerden anlamaktayız. O, gerçekleşmesini mümkün görmediği ve muhataba yarar sağlamayan meselelerin varsayımına karşı çıkmıştır. Örneğin şu rivayette bunu görmek mümkündür: Oruç tutmaya niyet etmiş birinin, yiyip içmeyi ne zaman bırakacağını soran birine Ebû Hanîfe, "fecir attığında" diye cevap vermiştir. Soruyu soran kişi, "Peki ya fecir gecenin ortasında doğarsa ne olacak?" diye sorunca, Ebû Hanîfe onu azarlamış ve cevap vermemiştir.77

Ebû Hanîfe'nin karşı çıktığı farazî meselelerden bir diğeri inatlaşma amacıyla sorulan meselelerdir. Nitekim o, “Bir kimse Allah resûlü için ‘Ben senin Allah'ın resûlü olduğunu biliyorum

\footnotetext{
${ }^{73}$ Kevserî, Bülûğu'l-Emânî fî Sîreti'l-İmâm Muhammed b. el-Hasen eş-Şeybânî. (b.y.: el-Mektebetü'l-Ezheriyye li't-Türâs, 1998), 6.

${ }^{74}$ İbn Ebi'l-'Avvâm, Fedâilü Ebî Hanîfe, 108; Bezzâzî, Menâkıbu Ebî Hanîfe, 2: 346.

${ }^{75}$ Hatîb, Tarîhu Medîneti's-Selâm, 15: 478-479; Bezzâzî, Menâkıbu Ebî Hanîfe 2: 179.

${ }^{76}$ İbn Hamdân, Sifetu'l-Fetvâ ve'l-Müftî ve'l-Müsteftî, 57.

77 İbn Ebi'l-'Avvâm, Fedâilü Ebî Hanîfe, 123; Hatîb, Tarîhu Medîneti's-Selâm, 15: 481-482.
} 
fakat seni öldürmek istiyorum' derse bu kimsenin hükmü nedir?" şeklindeki farazî bir soruya soruya “Bu mesele, mevzuyu karıştırmak isteyenlerin ileri sürdüğü meselelerdendir. Zira bir kimse, Hz. Peygamber'in Allah'ın resûlü olduğunu bilmesine rağmen onun öldürülmesini, ölmesini veya eziyet çekmesini istemesi mümkün değildir. Bu, en sevdiği biri hakkında, 'Seni ellerimle öldürmek, etini yemek istiyorum.' demesine benzer." demektedir. ${ }^{78}$ Bu örnekler Ebu Hanîfe'nin, farazî mesele üretirken ya da sorulan farazî bir meseleye cevap verirken ilmî hassasiyete sahip olduğu, bir fayda barındırmayan meselelerle alakadar olmadığını ve farazî fıkıh hususundaki hassasiyetini ve duruşunu göstermektedir.

Ebû Hanîfe'nin bazen imkânsız meselelere yer verdiği gözükür. Ancak bu türden meseleleri gerçek anlamda bir farazî fıkıh ameliyesi olarak görmek mümkün değildir. Örneğin ona göre, bir öldürme suçunda kısâs hükmü için suç aletinin kesici bir alet olması gereklidir. Ebû Hanîfe'ye, "Bir adam başka birini kafasına attığı bir kaya parçasıyla öldürse, kısâs var mıdır?" diye sorulduğunda, "Hayır kısâs yoktur. Adamın kafasına Ebû Kubeys dağını atıp öldürse de kısâs yoktur" cevabını vermiştir. ${ }^{79}$ Görüldüğü üzere Ebû Hanîfe, bu faraziyeyi, konuyla ilgili görüşünün kesinliğini göstermek için kullanmıştır. Ebû Hanîfe, gerçek anlamda böyle bir şeyin gerçekleşebileceğini söylemek istememiştir.

Ebû Hanîfe, gerçekleşmesi imkânsız farazî bir meselenin, şerî hükmün aklî tutarlılığına itiraz olarak öne sürülemeyeceği görüşündedir. Gerçekleşmeyecek bir ihtimalin varsayımı, hükmün uygulanabilirliğine halel getirmez. Onun bu görüşte olduğunu, lohusalığın (nifâs) doğumla birlikte mi yoksa doğumdan sonra mı başlayacağına yönelik, öğrencilerinden Ebû Yûsuf'la yapmış olduğu bir tartışmadan anlaşılır. Mesele ve bu yöndeki tartışma özetle şöyledir: Ebû Hanîfe, doğum sırasında rahmin açılmasını esas alarak lohusalığın doğumun başlamasıyla oluşacağı görüşündedir. Buna göre, ikizlere hamile bir kadının nifâsı ilk çocuğu doğurmasıyla başlar ve kırk gün devam eder. İkizler on gün arayla doğarsa, ikinci çocuğun doğumundan otuz gün sonra nifâs süresi bitmiş olur. Ebû Yûsuf, bu hükmün uygulanamayacağını ortaya koymak için "Söyler misin? Şayet iki çocuğun doğumu arasında kırk gün olsa ne olacak?" şeklinde farazî bir meseleyle itirazda bulunur. Ebû Hanîfe böyle bir şeyin olamayacağını söyler ve itirazı reddeder. Ebû Yûsuf, böyle bir şeyin gerçekleşeceğini varsaymasını ister. Ancak Ebû Hanîfe, "Ebû Yûsuf'un burnu sürtse bile bu durumda da ikinci çocukla birlikte kadının nifâsı biter" demiştir. ${ }^{80}$ Ebû Yûsuf bu varsayımla Ebû Hanîfe'ye aslında şu itirazda bulunmuştur: İkizlerden biri doğduğunda nifâs başlıyorsa kırk gün sonra doğacak diğer çocukla birlikte lohusalığın bitmesi gerekir. Bu durumda henüz doğumu bitmiş kan görmeye devam eden birinin lohusa olmadığına hükmedilmesi sonucu çıkar. Bu tutarsızlık olur. Ancak Ebû Hanîfe, ikizlerin kırk gün arayla doğumunu gerçekleşmeyecek bir varsayım olarak gördüğünden hüküm değişikliğine gitmemiş ve bu yöndeki aklî itirazı dikkate almamıştır.

\footnotetext{
78 İmam-1 A‘zam Ebû Hanîfe Nu’mân b. Sâbit, “el-‘Âlim ve'l-Müte‘allim”, İmam-ı Azam'ın Beş Eseri (Çev. Mustafa Öz). (İstanbul: İSAV Yayınları, 1992), 21.

${ }^{79}$ Ebû Osmân b. Bahr el-Câhiz, el-Beyân ve't-Tebyîn. (Kâhire: Mektebetü'l-Hâncî 1998), 2: 212.

${ }^{80}$ Serahsî, el-Mebsût, 3: 212-213.
} 


\section{Sonuç}

Ebû Hanîfe'nin farazî fıkhı kullanımına yönelik yaptığımız bu çalışmada onun hukuk anlayışının gelişiminde farazî fıkhın geleceğe yönelik bir hukuk inşasının ötesinde roller üstlendiği görülmüştür. Ondan önce de farazî fıkhın kullanıldığı görülse de o, bu yöntemi geliştirmiş ve bütün fürû konulara uyarlayarak sistemleştirmiştir. Onun, farazî fıkhı bu denli kullanımında çeşitli faktörler etkili olmuştur. Bölgenin demografik yapısındaki çeşitlilik nedeniyle karşılaşılan hadiselerin nicelik olarak artması ve nitelik olarak da giriftleşmesi, ilmî seyahatlerin artması nedeniyle bölgeye intikal eden meselelerde vakıa ve farazî ayrımının imkânsızlaşması, önceki nesillerden aktarılanlarla birlikte bölgede hayli hukukî problem (mesâil) birikimi gibi etkenler, farazî fıkhın gerekçesini oluşturmuştur. Ayrıca ehl-i re'yden olması cihetiyle fıkhî faaliyetlerinde aklî istidlâlin önemli bir yer işgal etmesi, sıhhati şüpheli rivayetleri aklî kıstaslarla değerlendirme gereksinimi, bölgede cedel ve münazaraya dayalı fıkhî faaliyetlerin revaçta olmasının yanında kendisinin de tartışmacı bir kimliğe sahip olması gibi faktörler de farazî fıkhı kullanmasında etkili olmuştur. Bunun yanı sıra Ebû Hanîfe, farazî meseleleri pratik ve teorik gayelerle kullandığı gibi hocalığını yaptığı ilim meclisine katılan talebelerinin (ashâb) eğitimlerinde pegadojik amaçlarla etkin bir şekilde kullanmıştır. Bu bakımdan Ebû Hanîfe, farazî fıkhı, hukuk düşüncesinin her alanına yerleştirmiş, bir ilim olarak fıkhın olmazsa olmaz unsuru görmüştür.

Farazî fıkıh ekseninde Ebû Hanîfe'ye yönelik eleştiriler, hem meseleleri aşırı detaylandırma hem de varsayımsal meseleleri rivayetleri değerlendirmede aklî araç olarak kullanmasına yöneliktir. Ancak kurgusal olaylar oluşturmak suretiyle fıkıh meselelerini detaylandırmasına yönelik eleştirilerin uzun soluklu oldukları söylenemez. Nitekim diğer mezhep mensupları da fıkıh düşüncelerini farazî meseleler, üstelik Ebû Hanîfe'nin bu çabalarının bir semeresi olan teliflerde yer alan meseleler üzerine inşa etmişler ve bundan dolayı ondan övgüyle bahsetmişlerdir. Ebû Hanîfe'nin, farazî meseleleri, rivayetleri değerlendirmede kullanmasına yönelik eleştirilerin ise ehl-i hadîsin farazî mesele özelinde yaptığı bir eleştiri değildir. Bu eleştiri ehl-i hadisin sahih olan hadisin kabulünde senedin sıhhatiyle yetinmeleri ve ayrıca aklî kıstaslara başvurmama prensibinden kaynaklanır. Ebû Hanîfe'nin, farazî meseleleri bu türden rivayetleri değerlendirmede aklî bir araç olarak kullanması, söz konusu eleştirinin temel sebebidir.

\section{Kaynakça}

Abdülazîz el-Buhârî, Alâüddîn Abdülazîz b. Ahmed b. Muhammed el-Buhârî, Keşfü'l-Esrâr 'an Usûli Fahri'l-İslâm el-Pezdevî. 4 cilt, thk. Abdullah Mahmûd Muhammed Ömer, Beyrut: Dâru'lKütübi'l-İlmiyye, 1997.

Apaydın, Yunus, "Bir Muhafazakar Reycilik Teorisyeni: Ebu Hanîfe”, İslami Araştırmalar Dergisi Ebu Hanife Özel Sayısı. 15/1-2 (2002).

Bâbertî, Ekmelüddîn Muhammed b. Muhammed, el-'inâye Şerhu'l-Hidâye. 10 cilt, Beyrut: Dârü'1Kütübi'l-ìlmiyye, 2003.

Bâbertî, en-Nüketü'z-Zarîfe fî̀ Tercîhi Mezhebi Ebî Hanîfe. Riyad: Câmi’atü'l-Melik Sü'ûd, 1997.

Bardakoğlu, Ali, "Hanefî Mezhebi", Türkiye Diyanet Vakfı İslâm Ansiklopedisi. 16: 1-21. Ankara: TDV Yayınları, 1997. 
Bayder, Osman, “Ebû Hanîfe'nin Kurucu İmam Olmasının Anlamı”, Devirleri Aydınlatan Meş'ale İmam$\imath$ A'zam Ulusal Sempozyum Tebliğler Kitabı. Eskişehir: Osmangazi Üniversitesi Yayınları, 2015.

Bedir, Mürtaza, Ebu Hanife-Entelektüel Biyografì. Ankara: Ay Yayınları, 2018.

Beyhakî, Ebû Bekr Ahmed b. Huseyn b. Ali, Menâkıbü'ş-Şâfî̀. 2 cilt, Kahire: Dârü't-Türâs, Kâhire, 1970.

Bezzâzî, Hâfızuddîn b. Muhammed el-Kerderî el-Fetâva'l-Bezzâziyye. Beyrut: el-Matba'atü'l-Kübra'lEmîriyye, 1310.

Bezzâzî, Hâfızuddîn b. Muhammed el-Kerderî, Menâkıbu Ebî Hanîfe. Beyrut: Dâru'l-Kitâbi'l-'Arabî, 1981.

Câhiz, Ebû Osmân b. Bahr, el-Beyân ve't-Tebyîn. 4 cilt, Kâhire: Mektebetü'1-Hâncî 1998.

Cevherî, İsmâil b. Hammâd, es-Sihâh Tâcu'l-Lü̆ğa ve Sihâhu'l-'Arabiyye. 4 cilt, thk. Ahmed Abdülğafûr Attâr, 4. Baskı, Beyrut: Dâru'l-i̇lm li'1-Melâyîn, 1990.

Cürcânî, Seyyid Şerîf Ali b. Muhammed, Mu'cemü't-Ta'rîfât. thk. Muhammed Sıddık el-Minşâvî, Kahire: Dâru'l-Fadîla, 1938.

Cüveynî, İmâmü'l-Haremeyn Ruknüddîn Abdülmelik b. Abdullâh, Muğ̣̂sü̈l-Halk fì Tercîhi'l-Kavli'lHakk. Misir: el-Matba'atü'l-Misriyye, 1934.

Dağbaşı, Gürkan "Abbasi Dönemi Çeviri Faaliyetleri”, Eski Yeni Anadolu İlahiyat Akademisi Araştırma Dergisi. 27 (2013), 177-187.

Dârimî, Ebû Muahmmed Abdullah b. Abdirrahmân ed-Dârimî, Sünenu'd-Dârimî, thk. Hüseyn Selîm Esed ed-Dârânî. 4 cilt, Riyâd: Dâru'l-Muğnî li'n-Neşri ve't-Tevzî‘, 1420.

Ebû Hanîfe, İmam-ı A‘zam Ebû Hanîfe Nu’mân b. Sâbit, "el-'Âlim ve'l-Müte‘allim”, İmam-ı Azam'ın Beş Eseri. Çev. Mustafa Öz, İstanbul: İSAV Yayınları, 1992.

Ebû Yûsuf, İhtilâfu Ebî Hanîfe ve İbn Ebî Leylâ. Haydarâbâd: Matba'atü'l-Vefâ, 1358.

Ebû Yûsuf, Ya'kûb b. İbrâhîm, Kitâb̈̈'l-Harâc. Beyrut: Dâru'l-Ma'rife, 1979.

Ebû Zehre, Muhammed, Ebû Hanîfe; Hayâtuh ve 'Asruh - Ârâuh ve Fikhuh. Kahire: Dâru'l-Fikri'l-'Arabî, 1976.

Emîr Padişah, Muhammed Emin, Teysîru't-Tahrîr. 4 cilt, Mısır: Matba'atü Mustafa el-Bâbî, 1351.

Ferâhîdî, Halîl b. Ahmed, Kitabu'l- 'Ayn. 4 cilt, thk. Abdülhamîd el-Hendâvî, Beyrut: Daru'l-Kutubi'lİlmiyye, 2003.

Fesevî, Ebû Yûsuf Ya 'kûb b. Süfyân, el-Ma'rifetü ve't-Tarîh. 3 cilt, Beyrut: Müessesetü'r-Risâle, 1981.

Gürler, Kadir, Ehl-i hadîsin Düşünce Yapısı -İlk Dönem Ehl-i hadîs Örneği. Bursa: Emin Yay., 2007.

Hacevî, Muhammed b. Hasan, el-Fikru's-Sâmî fî Tarîhi'l-Fıkhi'l-İslâmî. Beyrut: Dâru'l-Kutubi'l-İlmiyye, 1995.

Hasan, Ahmed, İlk Dönem İslâm Hukuk Biliminin Gelişimi. Çev. Haluk Songur, İstanbul: Rağbet Yayınları, 1999.

Hatîb el-Bağdâdî, el-Fakîh ve'l-Mütefakkih. thk. 'Âdil b. Yûsuf el-'Azâzî, 2 cilt, Riyâd: Dâru İbni'l-Cevzî, 1996. 
Hatîb el-Bağdâdî, Tarîhu Medîneti's-Selâm. thk. Beşşâr Ma'rûf, 17 cilt, Beyrut: Dâru'l-Ğarbi'l-İslâmî, 2001.

Hirş, Ernest, Hukuk Felsefesi ve Hukuk Sosyolojisi Dersleri. Ankara: Banka ve Ticaret Hukuku Araştırma Enstitüsü Türkiye İş Bankası Vakfı Sözkesen Matbaacılık, 2001.

Işıktaç, Yasemin, Hukuk Normunun Mantıksal Analiz ve Uygulaması. İstanbul: Filiz Kitabevi, 2004.

İbn Abdilberr, Ebû Ömer Yûsuf b. Abdillah el-Kurtubî, Câmi ‘u Beyâni'l-'İlmi ve Fadlihi. 2 cilt, Riyâd: Dâru İbni'l-Cevzî, 1994.

İbn Abdilberr, el-İntikâ' fî Fedâili'l-Eimmeti's-Selâseti'l-Fukahâ. Halep: Mektebetü'l-Metbû'âti'lİslâmiyye, 1997.

İbn Âbidîn Muhammed Emîn b. Ömer b. Abdilazîz el-Huseynî ed-Dımaşkî, Reddu'l-Muhtâr 'ale'dDurri'l-Muhtâr Şerhu Tenvîri'l-Ebsâr. 14 cilt, Riyâd: Dâru Âlemi'l-Kutub, 2003.

İbn Asâkir, Ebü'l-Kâsım Ali b. Hasan ed-Dımaşkî, Tarîhu Dımaşk. 80 cilt, Beyrut: Dâru'1-Fikr, 2000.

İbn Cinnî, Ebü'l-Feth Osmân b. Cinnî el-Mevsılî, el-Hasâis. 3 cilt, thk. Muhammed Ali Neccâr, b.y.: Dâru'l-Kütübi'l-Misriyye, ts.

İbn Ebi'l-'Avvâm, Ebü'l-Kasım Abdullah b. Muhammed, Fedâilü Ebî Hanîfe ve Ahbâruhû ve Menâkıbühü. Mekke: el-Mektebetü'l-İmdâdiyye, 2010.

İbn Hamdân, Ebû Abdillah Ahmed b. Hamdân, el-Harrânî el-Hanbelî, Sıfetu'l-Fetvâ ve'l-Müftî ve'lMüsteftî. thk. Nasıruddîn Albânî, Beyrut: el-Mektebu'l-İslâmî, 1380.

İbn Hazm, Ebû Muhammed Ali b. Ahmed, et-Takrîb li Haddi'l-Mantık. Beyrut: Daru İbn Hazm, 2007.

İbn Manzûr, Ebu'l-Fadl Cemâluddîn Muhammed b. Mukerrem, Lisânu'l-'Arab. 15 cilt, Beyrut: Dâru Sadır, 1414.

Kaya, Eyyüp Said Mezheplerin Teşekkülünden Sonra Fıkhî İstidlâl. İstanbul: Marmara Üniversitesi, Sosyal Bilimler Enstitüsü, Doktora Tezi, 2001.

Kevserî, Bülû̆ğu'l-Emânî fî Sîreti'l-İmâm Muhammed b. el-Hasen eş-Şeybânî. b.y.: el-Mektebetü'l-Ezheriyye li't-Türâs, 1998.

Kevserî, Muhammed Zahid, Te'nîbü'l-Hatîb 'alâ mâ Sâkahu fî Tercemeti Ebî Hanîfe mine'l-Ekâzîb. b.y.: y.y., 1990.

Kılıç, Halil, "İmâm Şâfiı̂'de Farazî Fıkıh”, İslam Düşüncesi Araştırmaları II. ed. Mahsum Aytepe-Hasan Kaya, Ankara: Araştırma yay., 2020, 27-60.

Kılıç, Halil, "İmâm Mâlik'in Hukuk Düşüncesinde Farazî Fıkıh", Din ve Bilim - Muş Alparslan Üniversitesi İslami İlimler Fakültesi Dergisi. 3 / 2 (Aralık 2020), 121-137.

Kılıç, Halil, İslam Hukuk Düşüncesinde Farazî Fıkıh. Erzurum: Atatürk Üniversitesi, Sosyal Bilimler Enstitüsü, Doktora Tezi, 2021.

Köse, Saffet, İslam Hukukuna Giriş. İstanbul: Hikmetevi Yayınları, 2015.

Mekkî, Muvaffak b. Ahmed, Menâkıbu Ebî Hanîfe. Beyrut: Dâru'l-Kitâbi'l-'Arabî, 1981. 
Muhaymîdî, Muhammed b. Abdillah b. Muhammed, "el-Fetvâ el-İftirâdiyye Mefhûmuhâ ve Ehemmiyyetuhâ ve Hukmuhâ", Mu'temeru'l-Fetvâ ve İstişrâfu'l-Mustakbel. Suud: Câmi'atu'lKasîm, 1434.

Nebhânî, Takıyyuddîn, eş-Şahsıyyetü'l-İslâmiyye. 3 cilt, Beyrut: Dâru'l-Ümme li't-Tıbâ‘a ve'n-Neşr, 2003.

Ömerî, Nâdiye Muhammed Şerîf, Neş'etü'l-Kıyâsi'l-Usûlî ve Tetavvüruhu: Dirâse fî̀ 'ilmi Usûli'l-Fıkh. Cize: Hicr li't-Tıbâ'a ve'n-Neşr, 1987.

Özen, Şükrü, İslam Hukuk Düşüncesinin Aklileşme Süreci Başlangıçtan Hicrî IV. Asrın Ortalarına Kadar. İstanbul: Marmara Üniversitesi, Sosyal Bilimler Enstitüsü, Doktora tezi, 1995.

Schacht, Joseph, The Origins of Muhammadan Jurisprudence. Oxford: The Clarendon Press, 1975.

Serahsî, Şemsüleimme Ebû Bekr Muhammed b. Ebî Sehl Ahmed, el-Mebsût. 30 cilt, thk. Halil Muhyiddîn el-Meys, Beyrut: Dâru'l-Fikr, 2000.

Şâtıbî, Ebû İshâk İbrâhim b. Mûsâ el- eş-Şâtıbî, el-Muvâfekât fî Usûli’ş-Şerî‘a. thk.: İbrâhîm Ramadân, 4 cilt, Beyrut: Dâru'1-Ma'rife, 2010.

Şelebî, Muhammed Mustafa, el-Medhal fi'l-Fikhi'l-İslâmî. Beyrut: ed-Daru'l-Câmi ‘iyye, 1985.

Tûfî, Necmüddîn Süleymân b. Abdilkavî el-Hanbelî, el-Işârâtü'l-İlâhiyye ile'l-Mebâhisi'l-Usûliyye. 3 cilt, Kahire: el-Fârûku'l-Hadîse li't-Tıbâ'a ve'n-Neşr, 2002.

Yaman, Ahmet; Çalış, Halit, İslâm Hukukuna Giriş. İstanbul: İFAV yay., 2014. 